\title{
A Floristic Study of the Vascular Plants of the Gypsum Hills and Redbed Plains Area of Southwestern Oklahoma
}

\author{
Submitted to the Faculty of the Graduate College of \\ Oklahoma State University in partial fulfillment of the \\ requirements for the Degree of Master of Science, \\ December 1975 \\ Susan C. Barber \\ Currently, Associate Provost and Professor of Biology \\ Oklahoma City University, Oklahoma City, OK 73106-1493 \\ E-mail: sbarberlokcu.edu
}

\begin{abstract}
The vascular floras of gypsum and redbed soils in southwestern Oklahoma were collected and studied during the growing season (April-October) of 1975. A total of 359 taxa and 230 genera and 63 families were included in the study. Thirteen taxa are considered to be gypsophiles and indicators of gypsum soils in Oklahoma. Nine taxa are considered calicoles occurring only on gypsum and limestone derived soils. Two introduced species, Bromus catharticus Vahl (syn. = Bromus willdenowii) and Caesalpinia gilliesii, are believed to be new additions to Oklahoma's flora.

Editor's note: The abstract and a brief summary of this thesis was published as "Floristic Components of the Gypsum Hills and Redbed Plains Area of Southwestern Oklahoma" in The Southwestern Naturalist 24(3):431437 September 15, 1979 and is included here by permission (SS)

\section{INTRODUCTION}

Gypsum outcrops and soils often support a distinctive flora. These endemic species presumably evolved in response to the rigorous conditions of high calcium sulfate content, drought, etc. Turner (1973) reports numerous new gypsophilous species from Mexico. In southwestern Oklahoma gypsum deposits are quite extensive and Waterfall (1950) listed new additions to the Oklahoma flora from Harmon and Jackson counties. This situation may parallel the well studied endemism on serpentine soils of California (Kruckeberg, 1951). Since gypsum often supports a distinctive group of plants and the southwestern part of the state has been seldom

collected, it seems that the floristic components of the gypsum and redbed areas could prove to be very interesting; therefore a study of the flora of the region was undertaken. The objectives of the study were (1) to describe the floras of gypsum and redbed plains geomorphic provinces in southwestern Oklahoma, (2) to determine similarities and differences in plant taxa of the two provinces, (3) to determine if the gypsite region taxa are unique to it or are characteristic of the redbed plains and/or gypsum floras, and (4) to determine if there are differences in the floras of edaphic areas within the gypsum province.

The study area is located within Harmon, Jackson, and Greer
\end{abstract}

Barber, S.C.

https://doi.org/10.22488/okstate.17.100059 
Oklahoma Native Plant Record

Volume 8, Number 1, December 2008

counties which are located in the southwestern corner of Oklahoma, the county seats being Hollis, Altus, and Mangum, respectively. The area is located approximately 55 miles northwest of Wichita Falls, Texas. The total land area is $1,272,256$ acres or 1.988 square miles. Oklahoma Highway 9 near the Salt Fork of the Red River constitutes the northern boundary for the collection area; the Red River, the southern boundary; the North Fork of the Red River, the eastern boundary; and the Oklahoma-Texas state line, the western boundary (Figure 1).

Three east-west transects were established in order to include major soil types and the distinct geomorphic provinces. Locations of the collection sites established along the transects are listed below and are indicated by the circles on the map of Figure 1 . collections were also made at other sites.

\begin{tabular}{l} 
REDBEDS \\
R19W, T2N, Sec. 15 \\
R19W, T2N, Sec. 17 \\
R20W, T1S, Sec. 19 \\
R20W, T1S, Sec. 20 \\
R21W, T2N, Sec. 13 \\
R22W, T2N, Sec. 13 \\
R22W, T2N, Sec. 15 \\
R23W, T2N, Sec. 3 \\
R23W, T2N, Sec. 6 \\
R23W, T5N, Sec. 18 \\
R24W, T1S, Sec. 12 \\
R26W, T4N, Sec. 3 \\
GYPSUM \\
R22W, T1N, Sec. 33 \\
R22W, T2N, Sec. 13 \\
R23W, T1S, Sec. 21 \\
R24W, T2N, Sec. 2 \\
R24W, T2N, Sec. 6 \\
R24W, T5N, Sec. 21 \\
R25W, T1N, Sec. 7 \\
SAND AREAS AND RIVER \\
\hline FLOODPLAIN \\
R20W, T2S, Sec. 11 \\
R21W, T2N, Sec. 16 \\
R22W, T4N, Sec. 1 \\
R26W, T5N, Sec. 24 \\
\end{tabular}

Specimens of the vascular flora of flora of the area were collected and identified. Collecting trips were made during the growing season starting April, 1975 and ending October, 1975. An attempt was made to collect the plants in different stages of flowering and fruiting. Voucher specimens were deposited in the Oklahoma state Herbarium (OKLA) and the Bebb Herbarium of the University of Oklahoma (OKL).

Geological and ecological considerations as well as a list of the 359 taxa are presented in subsequent chapters of this study.

\section{GEOLOGY AND TOPOGRAPHY}

Curtis and Ham (1972) describe twenty-six geomorphic provinces for Oklahoma. Of these twenty-six regions, three are found in the area of study: (1) the Mangum Gypsum Hills, (2) the Central Redbed Plains, and (3) the Western Sandstone Hills. The latter region is essentially composed of the same materials as the redbeds and is not discussed as a separate entity (Figure 2).

The most extensive of the geomorphic regions is the Central Redbed Plains area. These deposits were made during a time of sea withdrawal and extremely arid climates. The term redbeds applies to a series of brick-red shales and clays containing strata of other rock, occupying an area of approximately 50,000 square miles in southwestern Kansas, western Oklahoma, northern Texas, and extending westward to the Rocky Mountains. They are of Permian or Upper Carboniferous age, and rest directly above Pennsylvanian rocks to the east. In western Oklahoma the redbeds have been covered by other formations of a later geologic age. West of the salt Fork of the Red River are bluffs, mesas, and uplands of gypsum and sandstone that are intermingled with the redbeds. This area consists of red Permian clays 


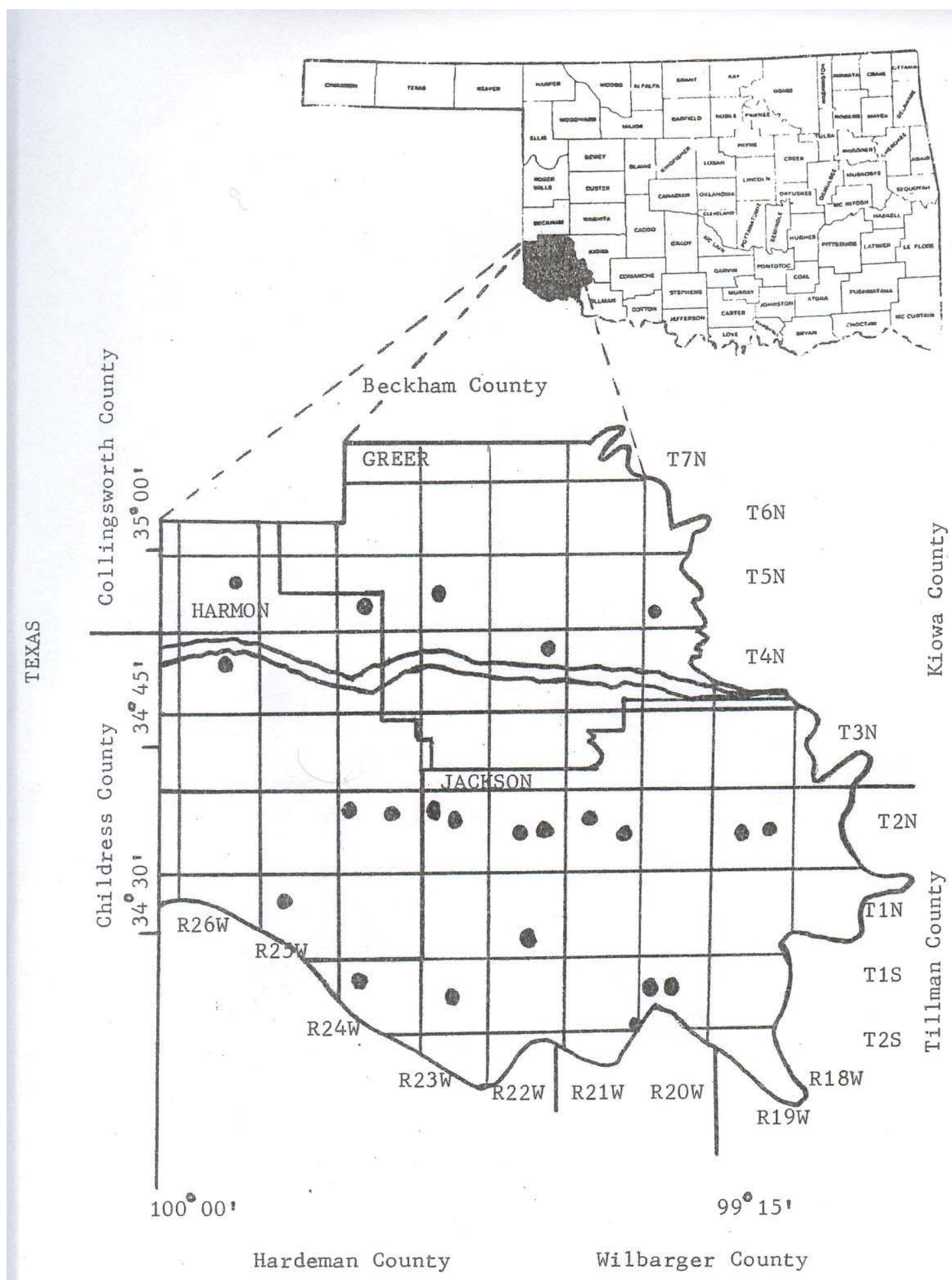

TEXAS

Figure 1. Location Map, Collection Sites Indicated by Solid Circles. 
Oklahoma Native Plant Record

Volume 8, Number 1, December 2008

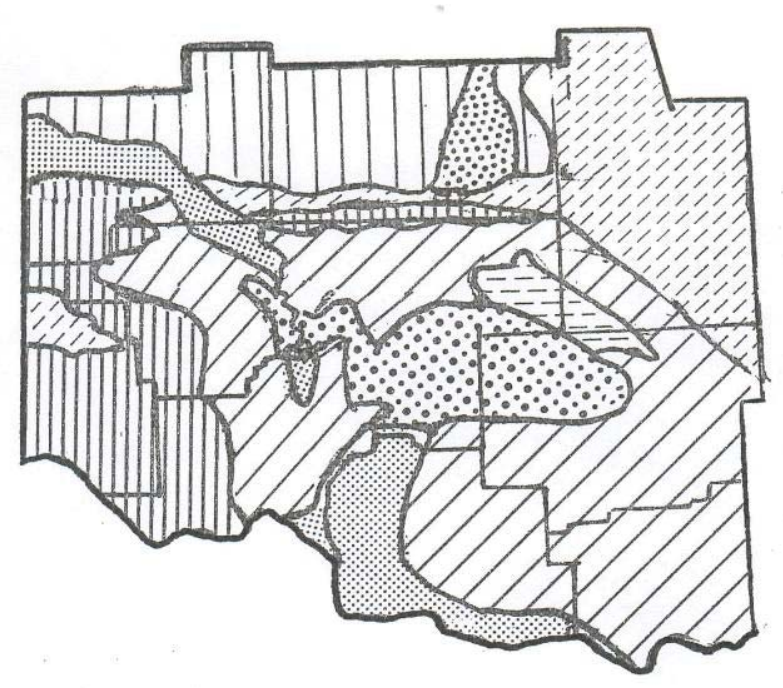

EIT Western Sandstone Hills

1 Western Sand Dune Belts

T1 Western Redbed Plains

E- Limestone Hills

$\because \because \because$ Granite Mountain Region

D/ Centra1 Redbed Plains

IIIIII Mangum Gypsum Hills

Weatherford Gypsum Hills

Figure 2. Geomorphic Provinces for Southwestern Oklahoma (Curtis and Ham, 1972).

and shales and has weathered into a gently rolling plain in which the hills seldom exceed 100 feet in height (Bruner, 1931). The area is well suited to the growth of grasses. The most extensive gypsum deposits in the United States, including the Oklahoma gypsum region, were laid in the Permian. The area extends almost uninterruptedly from central Iowa across Kansas, Oklahoma, and Texas. The most extensive gypsum deposits of this area are found in Oklahoma. The total amount of gypsum in the three counties is approximately 42,000,000,000 tons (Gould, 1910). There are three gypsum geomorphic provinces in Oklahoma: (1) the Cimarron Gypsum Hills (the Blaine Region of Gould, 1910), (2) the Weatherford Gypsum Hills, and (3) the Mangum Gypsum Hills (the Greer County Region of Gould, 1910). The Mangum Gypsum Hills are included within the study area. Stratification of the gypsum is erratic and the thickness of the formation varies a great deal. The gypsum does not form conspicuous hills, but appears on the surface in broken, not continuous ledges. The area is delimited from the redbeds by escarpments which are especially steep in southwestern Oklahoma. Snider (1913) described intermediates of the gypsum and the redbed plains which are deposits of gypsiferous clay known as gypsite. These deposits usually lie in valleys or flats below the gypsum ledges. These are probably formed by water which percolates through gypsum to the valley floor and evaporates from the surface leaving gypsum in a fine crystalline form mixed with the clay of the valley floors. In the field it was impossible to distinguish these soils from mixed redbed, gypsum soils.

The occurrence of copper minerals in Permian strata of western oklahoma has been known from the time of Marcy's exploration in 1850. The copper is generally found in flowerpot shales which are low relief areas. The shales are overlain by Duncan sandstone and underlain by thin dolomites. These areas make up a relatively small part of the study area.

Clifton (1928) made a study of the geology of Harmon, Greer, Jackson, and Tillman counties. The surface exposures within the limits of the three counties belong, for the most part, to the Permian system. Along the northeastern limits of the area

Barber, S.C. 
there is a line of pre-Cambrian exposures consisting of granite peaks and knobs. The Cimarron series is divided into three groups consisting of sandstone, shale, gypsum, and dolomite(Table I) .

TABLE I

\section{GEOLOGIC FORMATIONS EXPOSED AT THE SURFACE IN HARMON, GREER, AND JACKSON COUNTIES*}

\begin{tabular}{|l|l|l|}
\hline Series & Group & Formation \\
\hline Cimarron & Woodward & $\begin{array}{l}\text { Whitehorse } \\
\text { Sandstone } \\
\text { Dog Creek } \\
\text { Shale }\end{array}$ \\
\hline & Blaine & $\begin{array}{l}\text { Blaine } \\
\text { Gypsums }\end{array}$ \\
\hline & Enid & $\begin{array}{l}\text { Chickasha } \\
\text { Duncan } \\
\text { Hennessey } \\
\text { Garber }\end{array}$ \\
\hline
\end{tabular}

*From Clifton, 1928

The Woodward group, exposed only at the surface in Harmon county, consists of two formations, the Whitehorse sandstone and the Dog Creek shale formation. The Dog Creek shale formation appears as a surface outcrop in $\mathrm{T} 5 \mathrm{~N}$ and extends as far east as R24W. The Whitehorse sandstone overlies the Dog Creek shales in some areas.

Approximately the lower half of the formation is represented in the county.

The Blaine group, consisting only of the Blaine formation, is found in all three counties. The formation presents four or more series of discontinuous beds of gypsum and magnesium-calcium carbonate beds, with interbedded red clays and shales throughout the area it outcrops. Occasionally the gypsum beds have a tendency to erode locally in a series of outcrops. This formation covers the eastern portion of Harmon county, and the western portions of Jackson and Greer counties. Three of the four formations of the Enid group are found in Jackson and Greer counties. None of the rocks of these formations are exposed at the surface in Harmon County. The Hennessey, Duncan, and Chickasha are the formations. The Hennessey formation outcrops in the eastern part of Greer county and in the eastern and extreme southeastern sections of Jackson County. The Duncan and Chickasha formations appear as surface beds in the northern part of Greer County. In Jackson County the formation can be traced in an almost continuous line across the center of the county beginning near the town of Elmer.

Recent deposits consisting of sands, gravels, and alluvia border the streams in the area.

Harmon County is drained by the Red River and its tributaries, the principal of which are Lebos Creek, Salt Fork, and Elm Fork. Jackson county is also drained by the Red River and its tributaries, the North Fork, Salt Fork, and Gypsum Creek. Greer County is drained by Elm Fork, Salt Fork, and North Fork of the Red River. The drainage plain for all three counties slopes in a general southeast direction.

The intermingling of the gypsum and redbeds gives the area its characteristic topography. There is a considerable area having a relief dominated by low gypsum hills and escarpments. Otherwise, the topography is that of a level plain dissected by stream and erosion channels. The lowest elevation for the area is 1300 feet along the Red River in Jackson County, and the highest elevation is 1900 feet in northeastern Harmon county.

\section{SOILS}

The soils of the three counties range from shallow to deep and are nearly level to steep. In general, however, the soils are moderately sloping. Soil series are described

Barber, S.C. 
Oklahoma Native Plant Record

Volume 8, Number 1, December 2008

for only Jackson and Greer counties, while soil associations are described for all three counties. A series consists of all soils having like profiles and is named for a geographic feature near the area where the soils were first mapped. In contrast, soil associations consist of one or more major series and at least one minor series and are named for the major soils. These are much more useful to botanists because they cover large areas which are more readily compared and they often support distinctive vegetation types.

Table II enumerates the major soil series common to both Jackson and Greer counties. Tables III and IV list the other major soil series of Jackson and Greer counties, respectively. Since soil associations are more important to floristic botany, and the soil associations for each county are slightly different, each county will be dealt with separately.

Bailey and Graft (1961) described eight soil associations for Jackson County. A brief description for each one is given in Figure 3.

\section{The Tillman-Hollister}

association covers about 40 percent of the county. This association is found on a large, broad plain that is nearly level to gently sloping. It is broken occasionally by small areas of rough and broken land. In the level areas are the Tillman, Hollister, and Abilene soils. The steep areas are also composed of rough broken land. Most of these soils are cultivated and a great portion of the irrigated land in the county is in this association. Cotton, sorghum, and alfalfa are the principal irrigated crops of the association, and these crops and wheat are grown under dryland farming on this association.

\section{The Miles-Nobscot}

association covers about 13 percent of the county. The chief soils in this association are moderately sandy to sandy, and the slope ranges from nearly level to steep. The Miles soils, the most extensive of the series, have a surface soil that is a fine sandy loam. They are nearly level to moderately sloping. The Nobscot soils are sandier and more rolling than the Miles soils. The Miles soils of the association are best suited for cotton, grain sorghum, wheat, rye, and alfalfa. About two-thirds of the Nobscot soils are cultivated, and rye and grain sorghum are the crops grown. The rest of the association is used for rangeland.

\section{The LaCasa-Weymouth}

association makes up about 10 percent of the land area of the county. The soils are gently to stony soils or rock outcrops. The LaCasa and Weymouth soils are gently sloping, and the steep soils are members of the Harmon and Vernon series. Most of these soils are cultivated with wheat being the major crop. Moisture conservation and erosion control are major problems of dryland agriculture on this association.

\section{The Tipton-Enterprise-Tivoli} association lies along the rivers and occupies 15 percent of the county. The soils are mostly level to gently sloping. The Enterprise and Tivoli soils are near the rivers and the Tipton soils occupy the terrace areas. The Tipton 
and Enterprise soils are similar and are formed in very fine sands and silts that are blown in from river channels. Tivoli soils consist of wind-drifted sands and are billowy or dune-like. The Tipton and Enterprise soils are fertile and crops are grown on them. Tivoli soil is used for range and is only fair to poor for grazing.

5. The Vernon-Rough Broken Land association covers about 10 percent of the county. The Vernon soils are the smoother areas. Rough Broken Land consists of steep escarpments, canyons, and gullied areas. Included in these areas are beds of gypsum mixed with the clays of the redbeds. Harmon soils are shallow soils of this association. This association is not suitable for cultivation, but with proper management this land is often used for pasture.

6. The Spur-Port association covers about 6 percent of the county. This association lies along the major creeks. The Port soils are dark and occupy higher positions than the spur soils. About threefourths of this association are in cultivation and are used mainly for cotton, alfalfa, small grain, and sorghum.

TABLE II

MAJOR SOIL SERIES COMMON TO JACKSON AND GREER COUNTIES

\begin{tabular}{|c|c|c|c|c|}
\hline \multirow[b]{2}{*}{ Series } & \multirow[b]{2}{*}{ Surface Layer } & \multicolumn{3}{|c|}{ Factors of Formation } \\
\hline & & Parent Material & Vegetation & Slope \\
\hline Enterprise & $\begin{array}{l}\text { Very Fine } \\
\text { Sandy Loam }\end{array}$ & $\begin{array}{l}\text { Very fine sand } \\
\text { and silt; } \\
\text { Quaternary }\end{array}$ & $\begin{array}{l}\text { Shortgrass } \\
\text { Prairie }\end{array}$ & $\begin{array}{l}\text { Nearly level } \\
\text { to gently } \\
\text { sloping }\end{array}$ \\
\hline Hollister & $\begin{array}{l}\text { Clay to } \\
\text { Clay Loam }\end{array}$ & $\begin{array}{l}\text { Clayey Permian } \\
\text { redbeds }\end{array}$ & $\begin{array}{l}\text { Shortgrass } \\
\text { Prairie }\end{array}$ & $\begin{array}{l}\text { Nearly } \\
\text { level }\end{array}$ \\
\hline LaCasa & Clay loam & $\begin{array}{l}\text { Clayey Permain } \\
\text { redbeds }\end{array}$ & $\begin{array}{l}\text { Short Grass } \\
\text { Prairie }\end{array}$ & $\begin{array}{l}\text { Nearly } \\
\text { sloping }\end{array}$ \\
\hline Miles & $\begin{array}{l}\text { Fine Sandy } \\
\text { Loam }\end{array}$ & $\begin{array}{l}\text { Sandy earths of } \\
\text { Quaternary } \\
\text { deposits }\end{array}$ & $\begin{array}{l}\text { Sandsage } \\
\text { Grassland \& } \\
\text { Shortgrass } \\
\text { Prairie }\end{array}$ & $\begin{array}{l}\text { Nearly } \\
\text { level to } \\
\text { undulating }\end{array}$ \\
\hline Spur & Clay Loam & $\begin{array}{l}\text { Loamy alluvium } \\
\text { from Permian } \\
\text { redbeds }\end{array}$ & $\begin{array}{l}\text { Mixed-Grass } \\
\text { Prairie }\end{array}$ & $\begin{array}{l}\text { Nearly } \\
\text { level }\end{array}$ \\
\hline Tillman & Clay Loam & $\begin{array}{l}\text { Clayey Permian } \\
\text { redbeds }\end{array}$ & $\begin{array}{l}\text { Shortgrass } \\
\text { Prairie }\end{array}$ & $\begin{array}{l}\text { Nearly level } \\
\text { to gently } \\
\text { sloping }\end{array}$ \\
\hline Vernon & $\begin{array}{l}\text { Clay Loam } \\
\text { or Clay }\end{array}$ & $\begin{array}{l}\text { Clayey Permian } \\
\text { redbeds }\end{array}$ & $\begin{array}{l}\text { Shortgrass } \\
\text { Prairie }\end{array}$ & $\begin{array}{l}\text { Gently } \\
\text { sloping } \\
\text { to steep }\end{array}$ \\
\hline Weymouth & Clay Loam & $\begin{array}{l}\text { Calcareous } \\
\text { Permian } \\
\text { redbeds }\end{array}$ & $\begin{array}{l}\text { Shortgrass } \\
\text { Prairie }\end{array}$ & $\begin{array}{l}\text { Gently to } \\
\text { moderately } \\
\text { sloping }\end{array}$ \\
\hline Yahola & $\begin{array}{l}\text { Loamy Fine } \\
\text { Sand }\end{array}$ & $\begin{array}{l}\text { Loamy to } \\
\text { moderately } \\
\text { sandy alluvium }\end{array}$ & $\begin{array}{l}\text { Floodplain } \\
\text { Woodland }\end{array}$ & $\begin{array}{l}\text { Nearly } \\
\text { level }\end{array}$ \\
\hline
\end{tabular}

Barber, S.C. 
TABLE III

MAJOR SOIL SERIES OF JACKSON COUNTY

\begin{tabular}{|c|c|c|c|c|}
\hline \multirow[b]{2}{*}{ Series } & \multirow[b]{2}{*}{ Surface Layer } & \multicolumn{3}{|c|}{ Factors of Formation } \\
\hline & & Parent Material & Vegetation & Slope \\
\hline Abilene & Clay Loam & $\begin{array}{l}\text { Calcareous } \\
\text { clayey sediments }\end{array}$ & $\begin{array}{l}\text { Shortgrass } \\
\text { Prairie }\end{array}$ & $\begin{array}{l}\text { Nearly level } \\
\text { to gently } \\
\text { sloping }\end{array}$ \\
\hline Nobscot & Fine Sand & $\begin{array}{l}\text { Sandy earths of } \\
\text { Quaternary } \\
\text { deposits }\end{array}$ & $\begin{array}{l}\text { Sandsage } \\
\text { Grassland }\end{array}$ & $\begin{array}{l}\text { Gently to } \\
\text { strongly } \\
\text { sloping }\end{array}$ \\
\hline Tipton & Loam & $\begin{array}{l}\text { Loamy \& silty } \\
\text { alluvial } \\
\text { Quaternary } \\
\text { deposits }\end{array}$ & $\begin{array}{l}\text { Shortgrass } \\
\text { Prairie }\end{array}$ & $\begin{array}{l}\text { Nearly level } \\
\text { and gently } \\
\text { sloping }\end{array}$ \\
\hline Tivoli & Fine Sand & $\begin{array}{l}\text { Siliceous sands } \\
\text { of Quaternary } \\
\text { deposits }\end{array}$ & $\begin{array}{l}\text { Sandsage } \\
\text { Grassland }\end{array}$ & $\begin{array}{l}\text { Billowy } \\
\text { and duney }\end{array}$ \\
\hline
\end{tabular}

\section{TABLE IV MAJOR SOIL SERIES OF GREER COUNTY}

\begin{tabular}{|c|c|c|c|c|}
\hline \multirow[b]{2}{*}{ Series } & \multirow[b]{2}{*}{ Surface Layer } & \multicolumn{3}{|c|}{ Factors of Formation } \\
\hline & & Parent Material & Vegetation & Slope \\
\hline Lawton & Clay Loam & Granitic outwash & $\begin{array}{l}\text { Mixed-Grass } \\
\text { Prairie }\end{array}$ & $\begin{array}{l}\text { Nearly level } \\
\text { to strongly } \\
\text { sloping }\end{array}$ \\
\hline Springer & $\begin{array}{l}\text { Loamy Fine } \\
\text { Sand }\end{array}$ & $\begin{array}{l}\text { Old alluvium } \\
\text { reworked by wind }\end{array}$ & $\begin{array}{l}\text { Tallgrass } \\
\text { Prairie }\end{array}$ & $\begin{array}{l}\text { Nearly level } \\
\text { to strongly } \\
\text { sloping }\end{array}$ \\
\hline
\end{tabular}


Tilman-Hollister

[IIIII Miles-Nobscot

$\because$ LaCasa-Weymouth

Tipton-Enterprise

IiIy Vernon-Rough Broken

Spur»Port

Yahola

Granitic

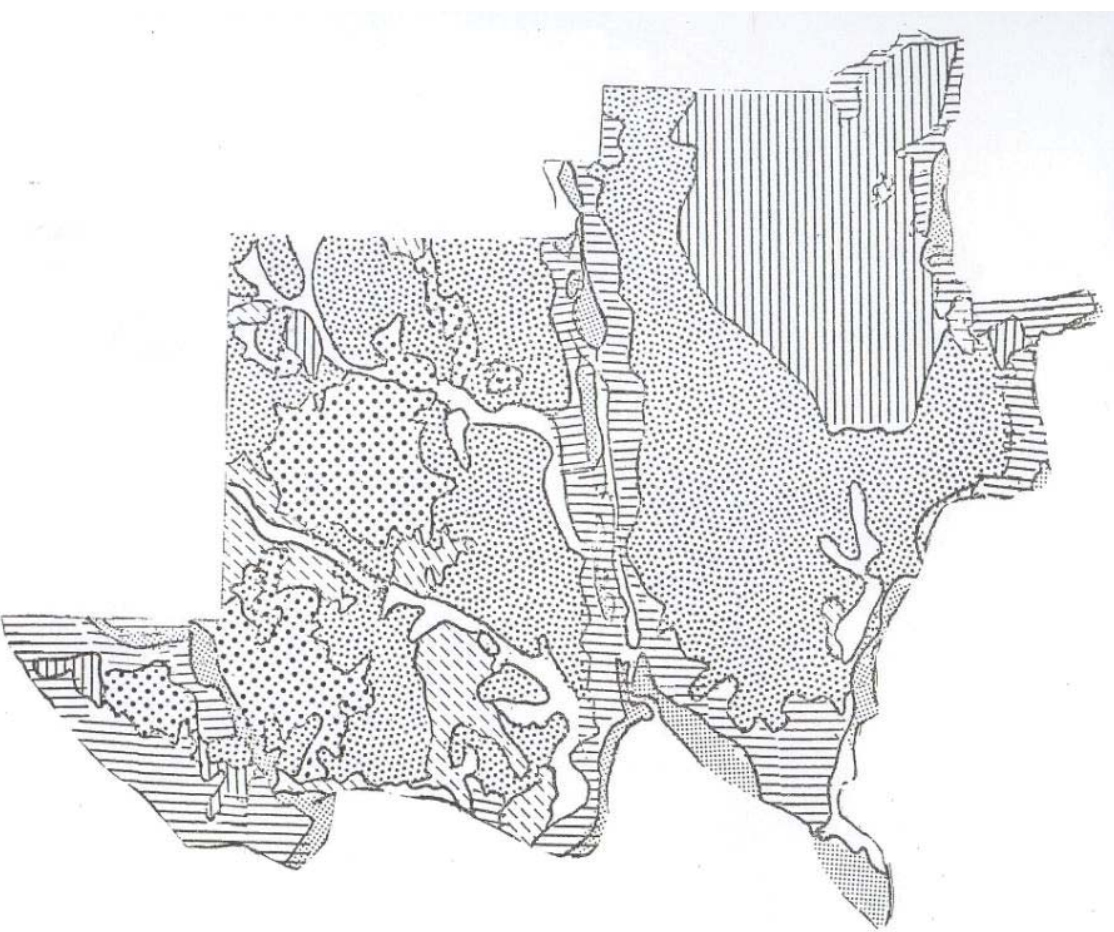

Figure 3. Soil Associations for Jackson County (Bailey and Graft, 1961).

7. The Alluvial Land-Yahola

association is on the flood plains of the rivers and covers about 6 percent of the county. The alluvial land is made up of sandy soils on the lower part of the flood plain. The Yahola soils are farther from the river channel and are less sandy. This association is used mainly for range. Some crops are grown on them.

\section{The Granitic Mountains}

association consists of stony granitic hills in the eastern part of the county and was not considered in this survey.

Frie, Brinlee, and Graft (1967) describe nine soil associations for Greer County. A brief description for each association is given in Figure 4.

1. The Miles-Springer-Tivoli association comprises 24 percent of the county. This soil association is on nearly level to strongly sloping uplands with a few dunes. The Miles soils make up most of the association and are nearly level to sloping. The Springer soils are gently to strongly sloping and the Tivoli soils are on stabilized dunes. Much of the acreage of this association is cultivated. Cotton is the main crop, but wheat, rye and grain sorghum are also grown. The land has to be well managed due to the high erosion rate and the rapid loss of fertility.

2. The St. Paul-WoodwardQuinlan association occurs in the north-central and northwestern parts of the county and is therefore outside the scope of this study area.

3. The Hollister-Tillman

association makes up 10 percent of the county. The 
Oklahoma Native Plant Record

Volume 8, Number 1, December 2008

soils are of broad uplands

that are formed in old alluvium and/or in material from clay and shale. The Hollister and Abilene soils are formed in calcareous old alluvium and the Tillman soils are nearly level and are formed in calcareous material. Nearly all of this association is cultivated. Wheat is the main crop, but other crops are also grown. These soils are also often irrigated.

4. The Lawton association makes up about 8 percent of the county. This association occupies nearly level or gently sloping uplands, broken by steep, stony hills. Much of this association is cultivated. Wheat and cotton are the main crops. Fields sown to winter wheat provide excellent pasture for beef cattle. The soils are also suitable for irrigation.

\section{The LaCasa-Weymouth}

association consists of gently sloping and sloping soils of the uplands. The LaCasa and Weymouth soils are formed in material from calcareous clay or shale. The Tarrant soils often intermingle with the Weymouth soils. Much of the land of this association is cultivated, mainly to wheat. The rest of the land is used for rangeland, but the ranges are difficult to manage.

6. The Badland-Rough Broken Land association makes up about 21 percent of the county. This association is rugged and is characterized by steep escarpments. Rocks of the Permian redbeds are exposed in a few areas. Much of this association is in native range and is used for grazing. Management is very difficult and forage production ranges from very poor to good. Where the soils contain gypsum care must be taken when selecting ponds.

7. The Sandy Alluvial LandYahola association covers 5 percent of the county. This association is made up of calcareous, nearly level soils on the flood plains of the rivers. The Yahola soils are, in general, found on higher areas. About 65 percent of the Yahola soils are cultivated, mainly to cotton, wheat, and alfalfa. Good range management is needed in this area.

8. The Spur-Mangum association makes up about 6 percent of the county. These are soils of the flood plains that formed in loamy and clayey alluvium. The Spur soils are mainly nearly level. The Mangum soils are dominant in nearly level areas that are occasionally overflowed. Nearly all of the Spur soils are cultivated. Wheat, cotton, and alfalfa are the main crops. The Mangum soils are mainly used for range rather than cultivation.

\section{The Tipton-Enterprise}

association covers about 3 percent of the county. These are nearly level to strongly sloping soils. These soils make up the terraces along the Red River. Wheat, cotton, and alfalfa are grown on nearly all the land. The soils of this association are fertile to highly fertile. A large acreage of the area is irrigated. 


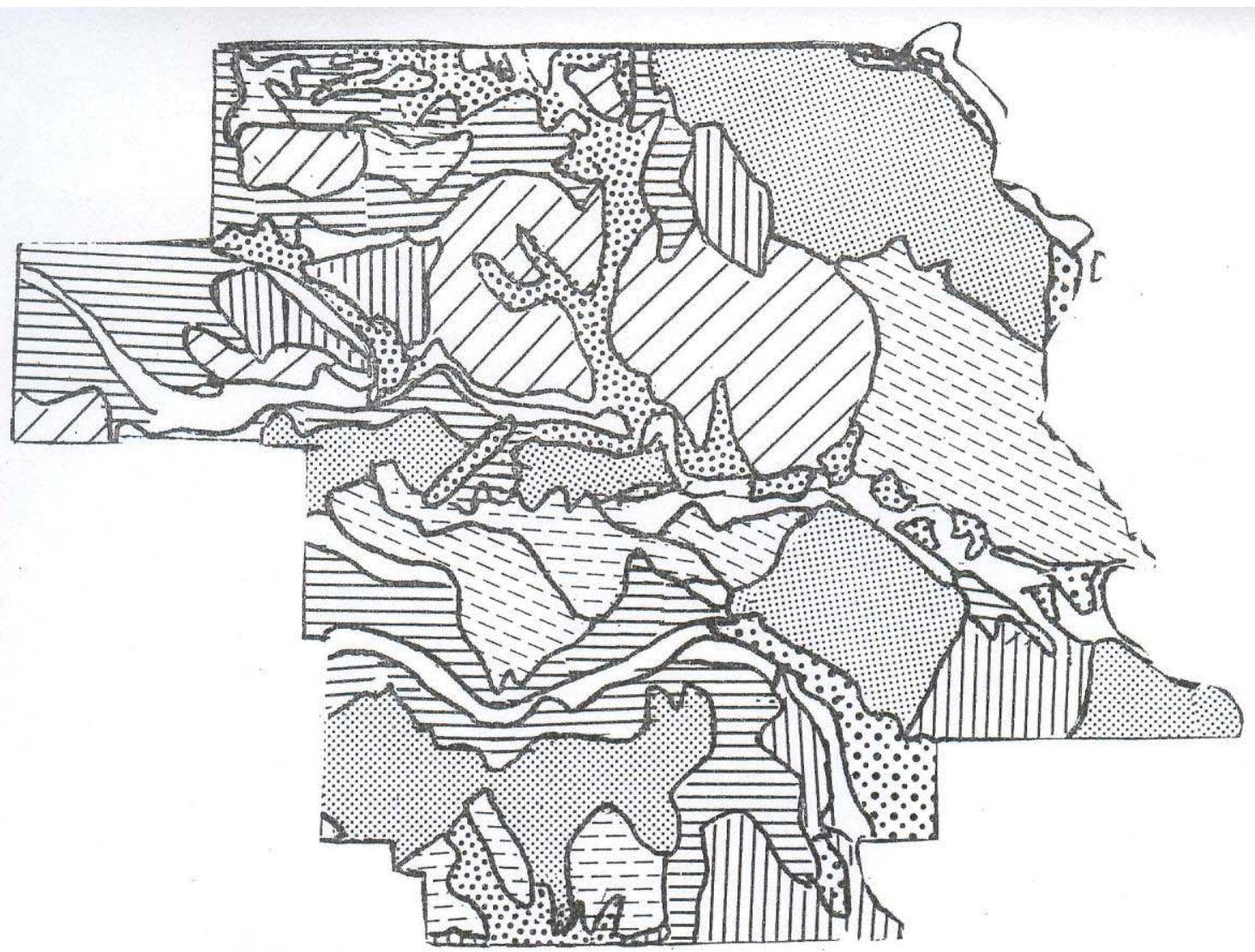

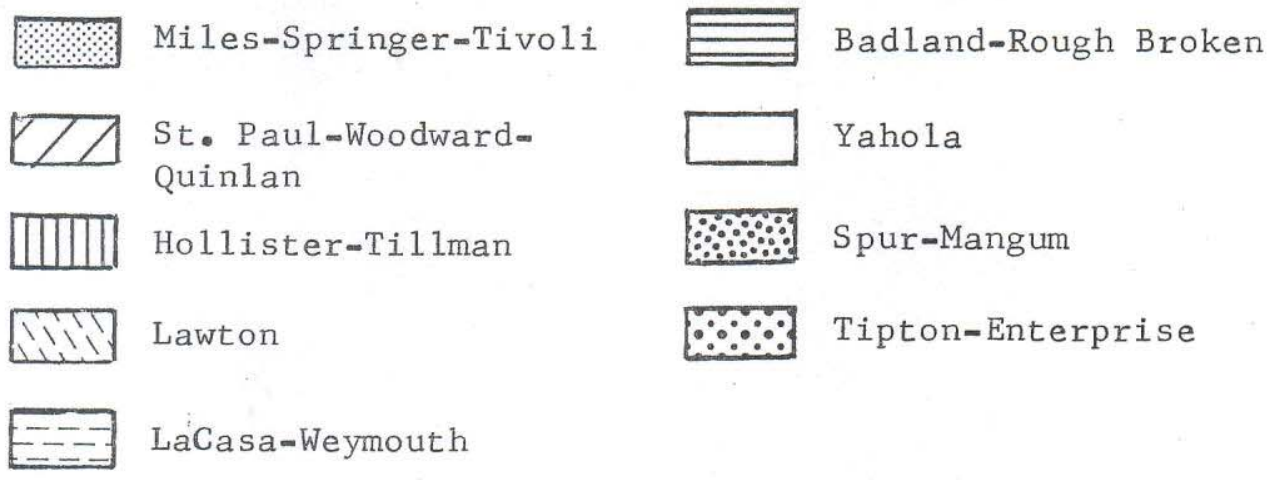

Figure 4. Soil Associations for Greer Gounty (Frie, Brinlee, and Graft, 1967)。

Barber, S.C. 
Oklahoma Native Plant Record

Volume 8, Number 1, December 2008

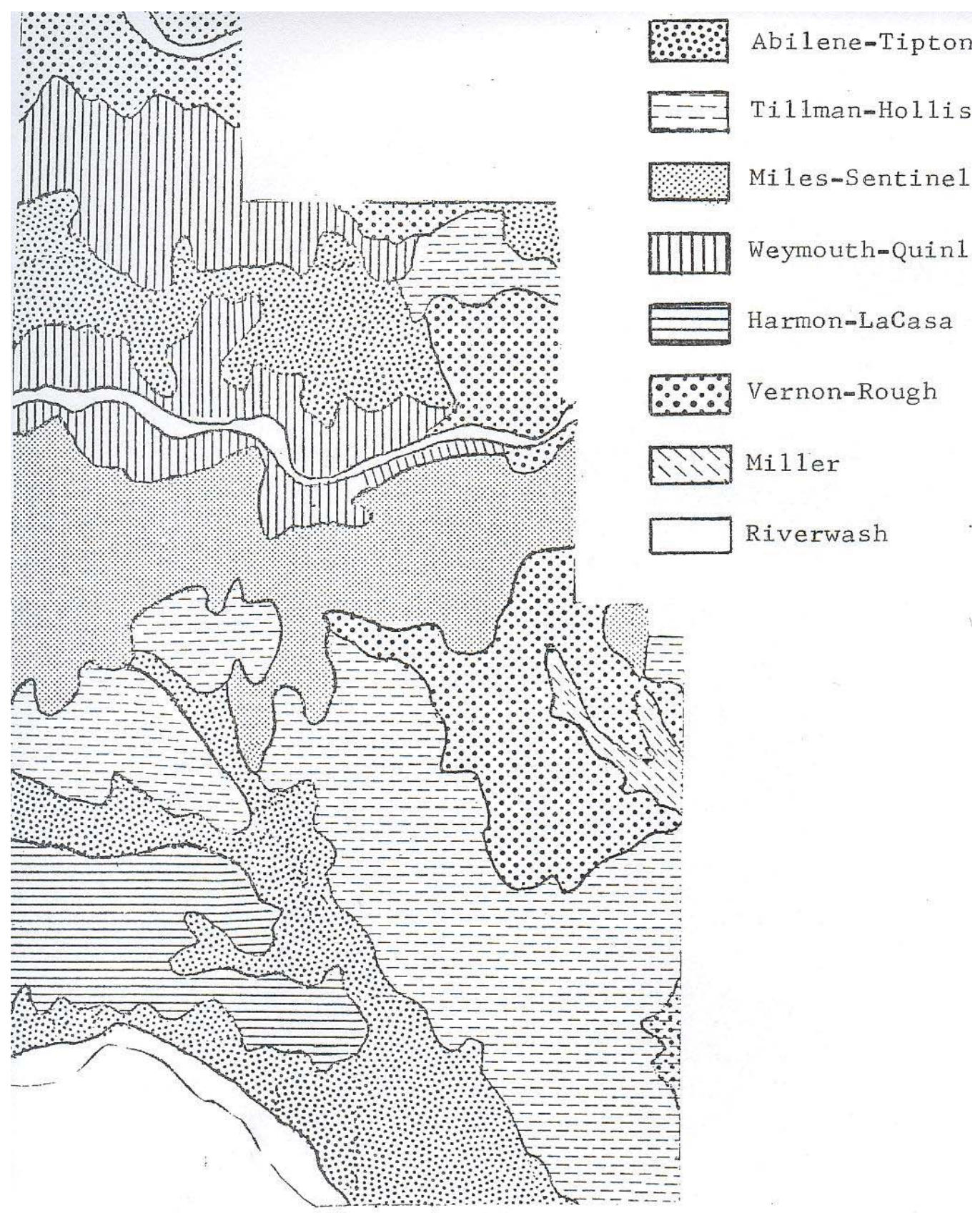

Pigure 5. Soil Associations for Harmon County (SCS, 1973).

Barber, S.C. 
No complete soil survey report for Harmon County has been published, but the Soil Conservation Service (1973) has mapped the major soil associations for the county (Figure 5). A brief description for each of the eight associations is given below.

\section{The Abilene-Tipton}

association is composed of deep upland soils with silty surfaces and permeable subsoils on nearly level to gently sloping topography. The main crops are cotton, wheat, milo, and alfalfa. The rangeland on this association is mostly on droughty soils. Mesquite is a problem on the rangeland of this association.

\section{The Tillman-Hollister}

association consists of deep upland soils with silty surfaces. They are nearly level to very gently sloping cotton is the main irrigated crop.

3. The Miles-Sentinel

association is composed of deep upland soils with sandy surfaces. The principal crops are sorghum and cotton. The major soil problem of the area is wind erosion.

\section{The Weymouth-Quinlan}

association consists of shallow to deep soils, loamy throughout. The soils are gently sloping to steeply sloping. Most of this association is used for rangeland.

\section{The Harmon-LaCasa}

association consists of shallow to shallow upland soils with loamy surfaces. The land is mainly used for rangeland, but mesquite is a problem on the ranges.

\section{The Vernon-Rough Broken Land}

\begin{abstract}
association is made up of very shallow to shallow upland soils with clayey surfaces. The slopes are gentle to steep. The soils are used primarily for rangeland. The shallow clayed soils cause drouthiness; therefore, maintaining an adequate vegetation cover is a problem.
\end{abstract}

7. The Miller association is composed of deep, clayey, bottomland soils used principally as cropland. Wheat has been almost exclusively the only crop grown on this soil.

8. The Riverwash association consists of deep sandy, bottomland soils used principally as rangeland. These soils produce a fair amount of forage, but the fertility is very low.

\section{CLIMATE}

The climate of the three county area is continental, warmtemperate, and subhumid. The major climatic variations are caused by the alternating movement of warm, moist air from the Gulf of Mexico and cool, dry air from the north. Daily and seasonal variations in the climate are often sudden and extreme. The months of greatest rainfall are April, May, and June and then the fall months of September and October. Most of the rains are of short duration and high intensity. The soils are driest in July and August when high temperatures and hot, dry winds remove moisture rapidly. Moisture is often removed from leaves faster than it can be supplied and the plants are unable to recover.

The average rainfall for Jackson County is 25 inches. The lowest amount ever recorded was 13.92 inches in 1917 and the

Barber, S.C. 
Oklahoma Native Plant Record

Volume 8, Number 1, December 2008

wettest year was 1941 with 49.30 inches. The average snowfall is 6.7 inches with snow rarely covering the ground for more than 2 weeks, generally only 2-4 days. The average growing season is 224 days. The average last frost in the spring is March 28 and the average first fall frost is November 7th (Bailey and Graft, 1961).

The average rainfall for Greer County is 23.68 inches. Annual amounts have ranged from a low of 10.86 inches in 1910 to as much as 45.13 inches in 1923. The average snowfall ranges from 6.5 inches in the southeastern part of the county to 8.5 inches in the northwestern part of the county. The growing season ranges from 209 days in the northwest to 225 days in the southeast. The average last spring freeze is November 4 th (Frie, Brinlee, and Graft, 1967).

The average rainfall for Harmon county is 23.2 inches. The amounts have ranged from a low of 9.79

inches in 1933 and a high of 45.15 inches in 1941. The average growing season is 225 days. The average last killing frost is March $30^{\text {th }}$ and the average first killing frost is November 10th (U.S.D.A. Soil Conservation Service, 1973).

Temperature and rainfall records were recorded at the Altus Irrigation Research Station, which is located in the south-central portion of the collection area in Jackson County. Evaporation data was taken from Altus Dam at Lake Altus in Greer County. Temperature is recorded in degrees Fahrenheit; precipitation and evaporation are recorded in inches.

climatically, this year was an unusual year for the study area, as indicated in Tables V-VII. Temperatures were generally below average for the year.

Precipitation, on the average, was higher in the summer months, but evaporation for the early part of the summer was greater than usual. In July 6.94 inches of the 7.13 inches of rain came in a three day period, the 24th through the 26th. Therefore, most of July was dry and the soil was baked. With the end of July and the first part of August came more rain. September and October, usually wet months, were exceptionally dry.

TABLE V

AVERAGE TEMPERATURES AND DEPARTURE FROM AVERAGE ( $\left.{ }^{\circ} \mathrm{F}\right)$ FOR THE MONTHS JANUARY THROUGH OCTOBER $1975^{\circ}$

\begin{tabular}{lcc}
\hline Month & Average & Departure \\
& & \\
\hline January & 42.2 & +2.2 \\
February & 39.4 & -5.2 \\
March & 50.1 & -1.3 \\
April & 60.7 & -2.6 \\
May & 70.2 & -1.3 \\
June & 78.7 & -1.6 \\
July & 8.0 & -4.3 \\
August & 81.0 & -1.6 \\
September & 70.5 & -5.1 \\
October & 65.4 & +0.6 \\
& & \\
aFrom Oklahoma Climatological \\
Data, Monthly Summaries, 1975.
\end{tabular}

TABLE VI
PRECIPITATION AND DEPARTURE FROM AVERAGE FOR THE MONTHS JANUARY THROUGH OCTOBER $1975^{a}$

\begin{tabular}{lll} 
Month & Evaporation & Depart \\
\hline January & 1.58 & +0.74 \\
February & 2.06 & +1.04 \\
March & 0.90 & -0.36 \\
April & 0.89 & -1.20 \\
May & 4.61 & +0.31 \\
June & 5.18 & +1.70 \\
July & 7.13 & +5.06 \\
August & 1.96 & -0.10 \\
September & 2.22 & -0.23 \\
October & 0.74 & -2.05
\end{tabular}

arom Oklahoma Climatological Data, Monthly Summaries, 1975. 
Oklahoma Native Plant Record

Volume 8, Number 1, December 2008

woodland in the three counties with 6,421 acres being used for crop production. The total crop acreage includes 25,382 with cover crops being used only to improve the land.

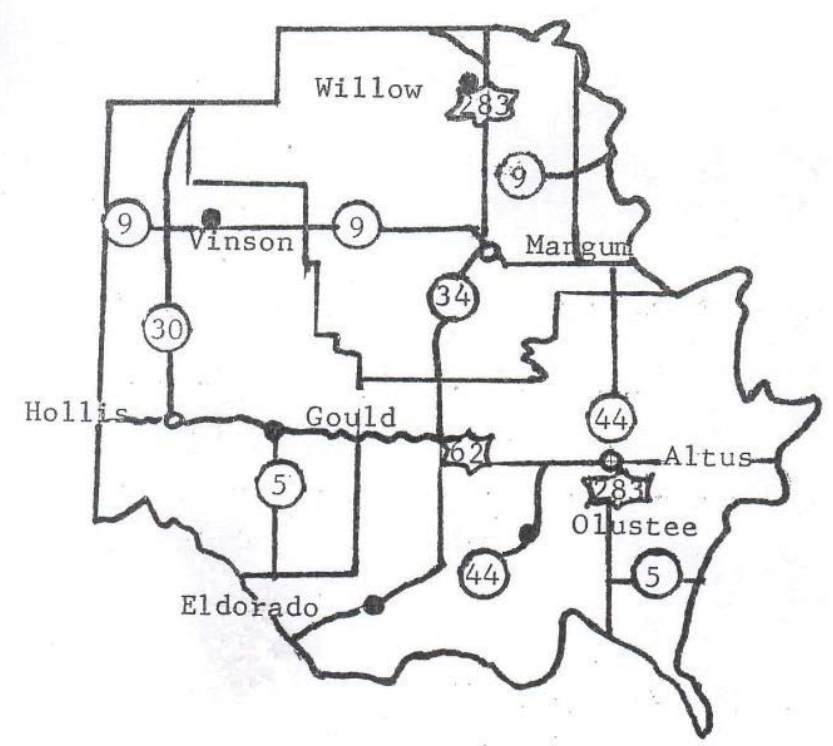

Figure 6. Towns and Major Highways (Modified from Official State Highway Map, 1973).

TABLE VIII

\section{SUMMARY OF ACREAGE USED FOR CROP PRODUCTION}

Industry
\begin{tabular}{|l|r|r|r|r|}
\hline Wheat & 128,595 & 47,617 & 68,714 & 244,926 \\
\hline Cotton & 40,722 & 30,634 & 24,239 & 95,595 \\
\hline Hay & 13,147 & 11,799 & 6,289 & 31,235 \\
\hline Sorghum & 13,111 & 10,709 & 6,109 & 29,929 \\
\hline $\begin{array}{l}\text { Peanuts } \\
\begin{array}{l}\text { Soybeans } \\
\text { Corn }\end{array}\end{array}$ & 1,537 & 268 & 526 & 2,311 \\
\hline $\begin{array}{l}\text { Total } \\
\text { Crops }\end{array}$ & 197,112 & 101,027 & 105,877 & 404,016 \\
\hline
\end{tabular}

The extensive use of the land for agricultural purposes has had a pronounced effect upon the vegetation. Indicators of overgrazing, such as Gutierrezia dracunculoides (DC.) Blake, are often quite abundant in the fields. Extensive cultivation of the land for crop plants has destroyed many of the habitats for the native plants.

Two industries of the area which have had an effect upon the vegetation are those of gypsum and copper mining. Between Elmer and Eldorado there is an extensive area of copper mining near creta. Republic Gypsum, located in Duke, has a mine near the plant (Johnson, 1954). The mining has also destroyed many of the habitats for the plants, but along the edges of the mining area, the native plants can still be found.

The three county area has not been very profitable for the oil and gas industry. Clifton (1928) did an extensive geological survey of the area with respect to oil and gas and predicted that the area probably would not produce much gas and oil. In 1963 there were thirty-one oil and gas industries in the three county area (Census of Mineral Industries, 1963). In 1967 the number had been reduced to fourteen (Census of Mineral Industries, 1967). The industry has undoubtedly had a small impact upon the vegetation of the area, but the effect is not as pronounced as the effect of the agricultural industry.

\section{HISTORY}

The first European to set foot in what is now western Oklahoma was Vasquez de Coronado in 1541. There were no botanists in the group, but in a report to the "Holy Catholic Caesarian Majesty" he noted (Featherly, p. 10), "We found no kind of wood in all these plains away from the gullies and rivers, which were very few". His description is an accurate one for the western part of Oklahoma (Featherly, 1943).

In the year 1601 Juan de Onate of Santa Fe crossed a part of what is now Oklahoma. He stated that the ground was useless for agriculture and suitable only for a hunting ground for savage tribes (Featherly, 1943). 
In 1820 Stephen Harriman Long was commissioned to command the "Yellowstone Expedition" from St. Louis to Wyoming (McKelvey, 1955). Dr. Edwin James was appointed to serve as botanist and geologist for the expedition. Traveling on horseback the group departed April 24, 1820. As they entered the Great Plains of Iowa and Missouri, James commented:

These vast plains in which the eye funds no object to rest upon are at first seen with surprise and please sure, but their uniformity at length becomes tiresome.... Nothing is more difficult than to estimate, by the eye, the distance of objects seen in these plains.... A small animal, as a wolf or turkey appears the magnitude of a horse. (McKelvey, p. 212)

As they crossed Nebraska, James noted changes of the vegetation. Prickly poppy (Argemone alba) and Adam's needles (Yucca angustifolia) were noted. As the expedition traveled farther west, desert plants, cacti, and sagebrush become more abundant. On June $26^{\text {th }}$ the group entered Colorado and explored the Rocky Mountains approximately one month. On July $24^{\text {th }}$ Long, James, and another member of the party went southward from Colorado to search for sources of the Red River. On August $17^{\text {th }}$ the three men crossed from Hemphill County, Texas into the Antelope Hills area of Roger Mills County, Oklahoma. They were to travel in oklahoma until September $13^{\text {th }}$. James, compiler of records for the expedition, was impressed by the elevated plain and stated:

The luxuriance and fineness of grasses, as well as the astonishing number and good condition of the herbivorous animals of this region clearly indicate its value for purposes of pasturage. (McKelvey, p. 232)
The three men went eastward from there into the Ozarks and on September $19^{\text {th }}$ crossed into Arkansas.

James $W$. Abert was commissioned by congress in 1845 to survey the Canadian River in western Oklahoma (Abert, 1846). The expedition left on August $9^{\text {th }}$ from Bent's Fort on the Arkansas River. Very little was recorded concerning the vegetation, but the following is his brief description of the area:

We noticed a profusion of prairie sage, Artemisia tridentate, being about the only shrub that grows in these sandy regions. This plant seems to love a dry and arid soil... In some places it grew so luxuriantly that the stalks might be used for fuel. We were disappointed in not seeing even one specimen of the sage cock, Tetrao upophrasianus, which is so extravagantly fond of feeding on this plant that its flesh becomes so embittered as to render it perfectly

uneatable. Not withstanding the abundance of the plant, we did not see a single specimen of this bird during the trip. Cacti were numerous, and a species of Cucurbitaceae, Cucurbita aurantia, bearing a small spherical gourd, orangecolored. These plants are characteristic of the dry sandy plains. (Abert, p. 14)

On september $20^{\text {th }}$ the group encountered the gypsum and Abert commented:

We continued to follow the river, and became involved in difficult ground, which was high and rough, composed of red clay filled with gypsum, which is found so generally to pervade this country. The waters percolating the immense masses of this mineral, separate the sulphuric acid from the lime, and acquire an extremely nauseous taste, 
Oklahoma Native Plant Record

Volume 8, Number 1, December 2008

anything but agreeable to wayworn travelers, although our animals appear to relish it much. (Abert, p. 93)

They were forced to follow a serpentine course of travel on account of deep ravines of red clay and gypsum buttes. On September 23 rd the group was 20 miles west of the Antelope buttes.

In 1852 Captain R. B. Marcy led an expedition to explore the Red River boundary between Texas and Oklahoma (March, 1854). The expedition went from Fort Arbuckle through the Wichita Mountains to the source of the North Fork of the Red River. Dr. G. G. Shumard, surgeon of the expedition, collected about 200 species of plants. Determinations of the plants were done by Dr. John Torrey, who reported that many of the plants were rare and that the flora resembled that of the upper portion of the Canadian River. Most of the plants on the list were from the Wichita Mountains. As the party rode through the Wichitas toward the Red River, Marcy (p. 12) noted:

As we advance, the country away from the borders of the watercourses becomes more barren and woodlands are less frequently met with; indeed, upon the river there is no other timber but cottonwood (Populus angulata) and elm (Ulmus americana), and these in very small quantities; for the most part the valley of the river along where we passed today is entirely destitute of trees.

He described the sand-hills to be ten to thirty feet high and the vegetation sparse with weeds, grapevines, and plum bushes. They met Chief CanajeHexie of the Wichita tribe as they were leaving the mountains. He told them (Marcy, p. 17-18), "When you should leave the mountains to go down to the river, the country will be flat prairie country, totally destitute of water, wood or grass and the only substitute for fuel would be buffalo 'chips'."

As the party moved out of the mountains onto the prairie, March described the area as having the appearance of a meadow that has been recently mowed close to the earth due to the buffalo grass. He described the river banks as having mesquite trees and grama grasses and the sandstone hills with weeds and dwarf oaks. The group had hopes that the descriptions of the area that the Indians had given were erroneous. They soon discovered, however, that they were not. The water in the Salt Fork was bitter and unpalatable and caused nausea. The group encountered gypsum forming an immense belt. He described it as being much elevated above the surrounding country, very smooth, and level, spreading out in every direction without trees or shrubs --- "a barren solitude".

Captain Whipple headed a survey party to explore a route for a railroad from the Mississippi River to the Pacific coast in 1853. Dr. J. M. Bigelow was the botanist of the expedition and collected 125 species. Drs. John Torrey and Asa Gray wrote the botanical descriptions for the plants collected on the expedition (Bigelow, 1855).

As the group entered the western part of Oklahoma they noted gypsum in every variety of form and that there was a lack of trees and scarcity of grass.

They crossed Elm and Gypsum creeks and passed through a new sandstone that the geologist named "new red". Gypsum beds outcrop in these sandstones. The party camped in the Antelope Hills area of scanty grass relieved only by red gullies and occasional ravines.

Bigelow (1855) noted the first appearance of grama grass on the north side of the Canadian River at longitude $96^{\circ}$ west. He noted the fact that grama grass and

Barber, S.C. 
buffalo grass are important because they retain nutritive quality all year round and that they are only well adapted to arid climates in their native states. Apart from the grasses, the most notable plants were evening primrose, Ambrosia, and golden rods on the plains; and prairie plums on the streams. The entire area was described by Bigelow as having a considerable number of Cactaceae, especially opuntia macrorhiza. From Oklahoma the party went to the Pecos and Rio Grande river valleys.

From 1875-1877 Dr. T. E. Wilcox collected plants in what is now western Oklahoma and the determinations were done by Alphonso Wood. No further details of the excursions were given (Henson, 1941).

More recent studies of the area are very few. In 1932 a student at the University of Oklahoma, Rotha Zelma Bull, compiled a list of plants of Greer county as part of her master's program. The study area included the extension of the Wichita system into the southwestern corner of the state.

\section{ECOLOGICAL CONSIDERATIONS}

Blair and Hubbell (1938) list two biotic districts within the boundaries of the study area, the Mesquite Plains and Mixed-grass Plains districts.

The Mesquite Plains district is included to a greater extent in the gypsum hills region and only to a lesser degree in the redbed plains district. This province takes in approximately one-half of the land area included in the study. It includes vegetation mostly of the Mangum Gypsum Hills geomorphic province and soils of the Tillman-Hollister, LaCasaWeymouth, and Vernon-Rough Broken land associations. The principal vegetation is a mesquite grassland type with mesquite (Prosopis glandulosa) being the dominant woody vegetation and buffalo grass
(Bouteloua dactyloides) as the dominant herbaceous species. Desert cactus (Cylindropuntia leptocaulis) is also abundant. Scirpus marshes are quite often observed around the mouths of the creeks in this district.

The Mixed-grass Plains district comprises all of western Oklahoma except the Panhandle and the Wichita Mountains district. The district includes vegetation both of the Central Redbed Plains and the Mangum Gypsum Hills geomorphic provinces. The soils are basically of the Tillman-Hollister and Miles-Sentinel soil associations. The principal plants of the district are the grama grasses, blue grama (Bouteloua gracilis), hairy grama ( $B$. hirsuta), sideoats grama (B. curtipendula), buffalograss, and little bluestem Schizachyrium scoparium). On the deeper soils western wheatgrass (Pascopyrum smithii) and silver bluestem (Bothriochloa saccharoides) are abundant.

Within each biotic district distinctive plant associations and communities can be seen. Six plant associations are included in the study area, mixed grass eroded plains, mesquite grassland, sandsage grassland, shinnery oak grassland, woodland of creek and river floodplains, and aquatic communities (Figure 7).

The most extensive plant association is that of the mixedgrass prairie type which includes two distinct grassland communities. The first community is that of shallow soils mostly of the Vernon-Rough Broken land association and generally includes the grassland of the gypsum hills(Figures 8 \& 9).

In early spring very few grasses are in flower, but various forbs dominate the landscape which includes the following:

false nightshade (Chamaesaracha coniodes), (Cymopterus macrorhizus), puccon (Lithospermum incisum, Indian

Barber, S.C. 
Oklahoma Native Plant Record

Volume 8, Number 1, December 2008

paintbrush (Castilleja purpurea

var. citrine) rose vervain

(Glandularia canadensis), Texas yellow star (Lindheimera texana), flax (Linum rigidum), and prairie flax (Linum pratense).

In late spring, late April through May still another set of forbs dominates the scene:

loco weeds (Astragalus racemosus and other Astragalus species), evening primrose (Calylophus hartweggii, var. pubescens), paper flower (Psilostrophe villosa), aster (Aster leucelene), skull cap (Scutellaria drummondii), bladder-pod (Lesquerella gordonii), (Nama stevensii), lazy daisy (Aphanostephus ramosisimus), beard tongue (Penstemon fenderli), scarlet globe mallow (Sphaeralcea coccinea), (Happlopappus spinulosis), lemon beebalm (Monarda citridora), and (Phacelia integrifolia).

By June the grasses have started flowering and the forbs are still abundant. The forbs include:

(Dalea enneandra), mock pennyroyal (Hedeoma drummondii), prairie clover (Dalea candida var.

oligophylla, basket flower (Centaurea americana), stick leaf (Mentzelia nuda and other Mentzelia species),

(Haploesthes greggii), and evening primrose (Calylophus serrulatus).

The grasses include:

tumblegrass (Schedonnardus paniculatus), white tridens (Tridens albescens), tobosa (Hilaria mutica), (Erioneuron pilosum), and Canada wild rye (Elymus canadensis).

From July until October the dominant grasses are flowering and dominate the landscape:

blue grama, hairy grama, sideoats grama, sand dropseed (Sporobolus cryptandrus), (Tridens muticus var. elongatus), little bluestem, and tall dropseed (Sporobolus asper).

Numerous forbs are also abundant until frost. These include:

scurfy pea (Psoralidium tenuiflora), Missouri goldenrod (Solidago missourensis), and bluet (Stenaria nigricans).

The second grassland community of mixed grass eroded plains consists mostly of TillmanHollister and Miles-Sentinel soil associations which are deep upland soils. In early spring forbs and winter annuals dominate the scene (Figures 10 \& 11). They include:

common speedwell (Veronica arvensis), purslane speedwell (Veronica peregrina), creeping lady's sorrel (Oxalis corniculata), tansy mustards (Descurainia pinnata and D. sophia), shepherd's purse (Capsella bursa-pastoris), mousetail (Myosurus minimus), plaintain (Plantago purshii), loco weed, bladder pod, prairie flax, windflower (Anemone caroliniana), Indian paintbrush, false dandelion (Pyrrhopappus pauciflorus), Englemann daisy (Engelmannia peristenia) spiderwort (Tradescantia ohiensis), wine cup (Callirhoe involucrata), rabbit-tobacco (Evax verna), oats (Avena sativa), Japanese brome (Bromus japonicus), thistle (Cirsium texanum), canary grass (Phalaris caroliniana), (Pediomelum cuspidatum), zinnia (Zinnia grandiflora), skull-cap (Scutellaria wrightii), and prickly pear (Opuntia 


\section{humifusa).}

By the summer another set of forbs is in full flower. They include:

widow's tears (Commelina erecta), prickly poppy (Argemone polyanthemos), sensitive briar (Mimosa microphylla), fern acacia (Acacia angustissima var. hirta), (Nama hispidum), and golden aster (Heterotheca canescens).

A few grasses have started to flower by June. These include:

\author{
rabbitfoot grass (Polypogon \\ monspeliensis), side-oats \\ grama, western wheatgrass, and \\ prairie three-awn (Aristida \\ purpeurea and other Aristida \\ species). \\ From August through October, \\ the dominant grasses are in full \\ flower. These include: \\ blue grama, hairy grama, \\ bristle grass (Setaria \\ viridis), silver bluestem, tall \\ dropseed, big bluestem \\ (Andropogon gerardii), little \\ bluestem, purple top (Tridens \\ flavus), and annual three-awn \\ (Aristida oligantha).
}

\section{Forbs that are present in the fall include:}

(Palafoxia sphacelata), whitlow-wort (Paronychia jamesii), ironweed (Vernonia baldwinii), dotted gay-feather (Liatris punctata), matchweed Gutierrezia sarothae), annual buckwheat (Eriogonum annum), and blue sage (Salvia azurea).

The mesquite grassland association can also be divided into two grassland types. The two communities vary little from the grassland communities of the mixed eroded plain association. In aspect they are the same with the exception of mesquite, and abrojo
(Cylindropuntia davisii), which are dominant life forms on the deeper soils and Mormon's tea (Ephedra antisyphilitica), and buckthorn (Ziziphus obtusifolia), are dominant life forms on the typically Rough Broken land or gypsum soils.

One of the most distinctive associations of the mixed grass eroded plains district is that of the Sandsage grassland which predominates on sand dunes on the north side of most streams (Figure 12). Sandsage (Artemisia filifoliai), sand plum (Prunus angustifolia), lemon sumac (Rhus aromatica), and sand bluestem (Andropogon halii) are the most distinctive indicators of the stabilized dune areas. The vegetation of the sand area appears much more distinct than that of the other associations.

In the spring mostly forbs are blooming, with a few grasses intermingled. The list includes:

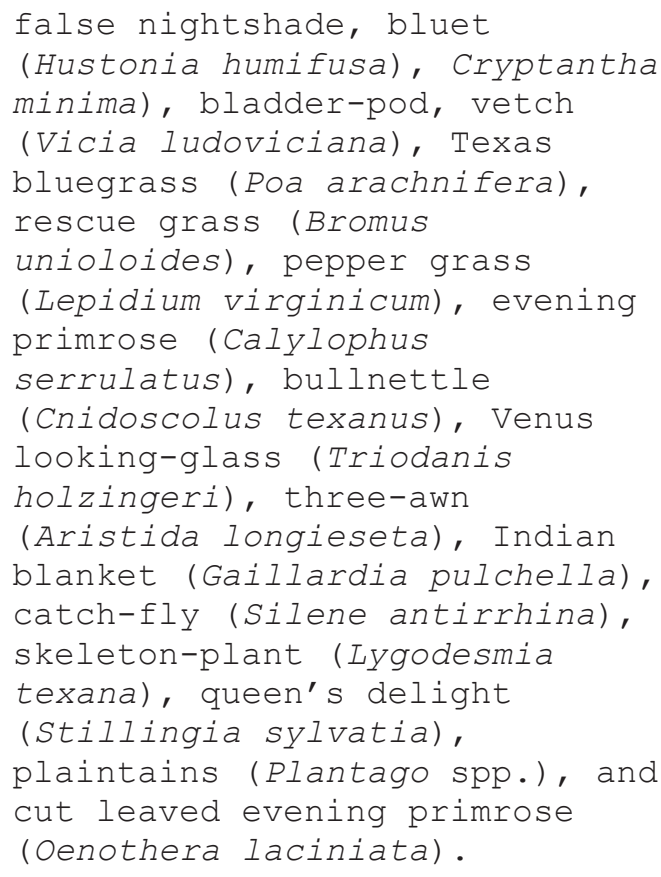

By the beginning of the summer the area is still dominated by forbs, but the grasses are beginning to flower also. The forbs include:

$$
\text { widow's tears, thistle, scarlet }
$$


Oklahoma Native Plant Record

Volume 8, Number 1, December 2008

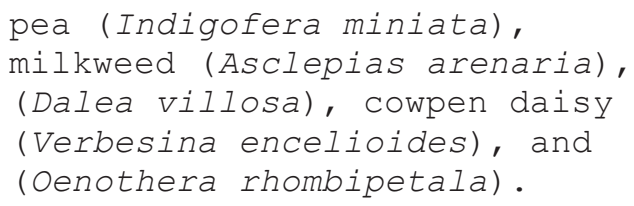

The grasses include:

rabbitfoot grass, hooded

fingergrass (Chloris

cucullata), sand dropseed, and silver bluestem.

With the coming of fall, still mostly forbs are dominant. Unlike the other associations where grasses are the main plants in the fall, forbs still dominate in this vegetation type. The grasses include:

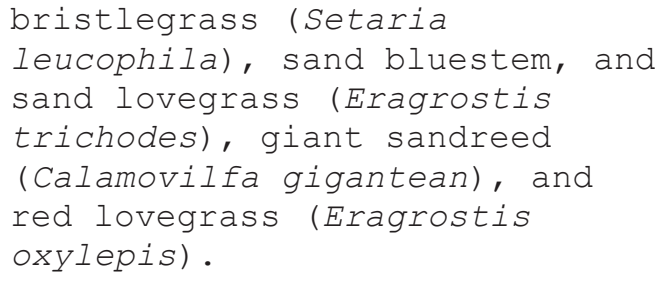

The fall forbs are mostly members of the compositae. The list includes:

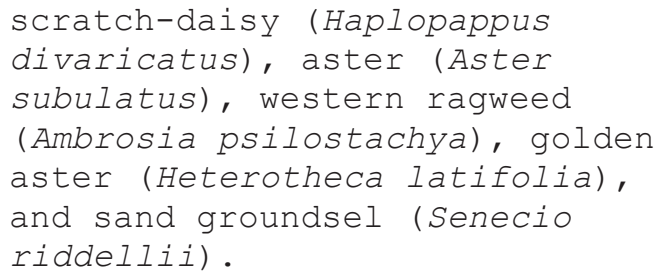

The shinnery oak association is also a sand association and has essentially the same dominant species as the sandsage grassland area except that shinnery oak (Quercus harvardii) is the dominant species. Other dominants such as sand plum and sand lovegrass, etc. are present.

Another plant association of the study area is that of the woodland of the creeks and river flood plains (Figure 13). The woody vegetation includes:

cottonwood (Populus deltoides), black willow (Salix nigra),

\begin{abstract}
American elm (Ulmus americana), hackberry (Celtis spp.), soapberry (Sapindus saponaria var. drummondii), and salt cedar (Tamarix gallica).
\end{abstract}

The understory includes:

rush (Schoenoplectus americanus), switchgrass (Panicum virgatum), Johnson grass (Sorghum halepense), barnyard grass (Echinochloa crusgalli), nutgrass (Cyperus uniflorus), saltgrass (Distichlis spicata var. stricta), canela (Pluchea odorata var. odorata), water pimpernel (Samolus ebracteatus), smartweed (Polygonum lapthifolium), and cockle bur (Xanthium strumarium).

The final community is comprised of the plants from the stock ponds, the aquatic community. These ponds are temporary and tend to have a high evaporation rate during the summer months, therefore the aquatics of these communities are temporal. The pond plants include:
cattail (Typha angustifolia), smartweed (Polygonum pensylvanicum), water clover (Marsilea vestita), tooth-cup (Ammania coccinea), sneezeweed (Helenium microcephalum), and spikerushes (Eleocharis macrostachya and E. compressa).

One other area needs to be discussed. Shelter belts are common in the southwestern part of the state. These were probably established in the 1930's during the "Dust bowl" days. This accounts for some unusual range extensions occurring in the area including:

green ash (Fraxinus pennsylvanica), honey locust (Gleditsia triacanthos), and desert willow (Chilopsis linearis). 


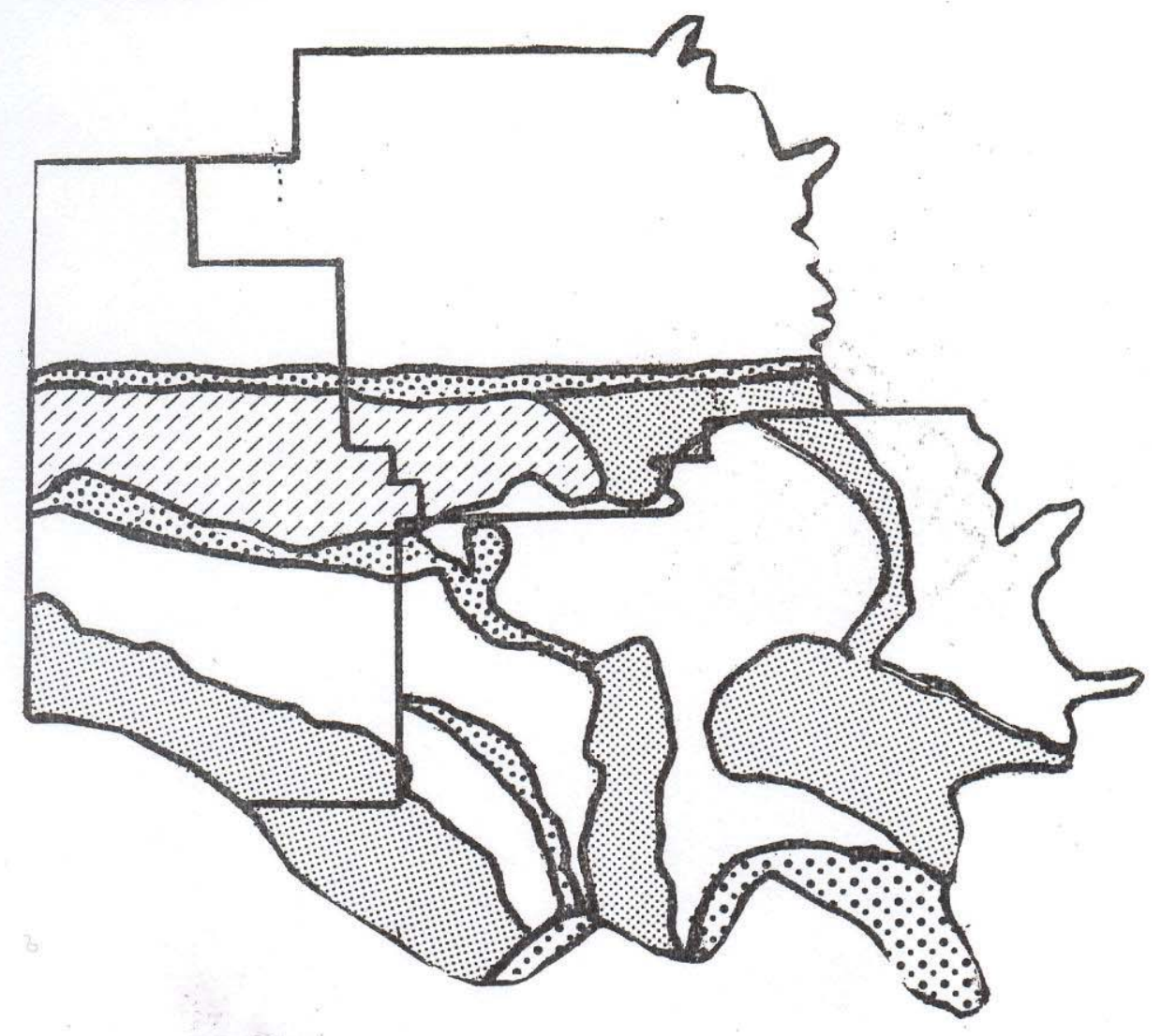

ए Mixed-Gnass Eroded Plain

$\because \because \because$ Sandsage Grassland

III Shinnery-Oak Grassland

Mesquite Grassland
$\vdots$ Woodland of Creeks and River Floodplains

Figure 7. Plant Associations. 
Oklahoma Native Plant Record

Volume 8, Number 1, December 2008
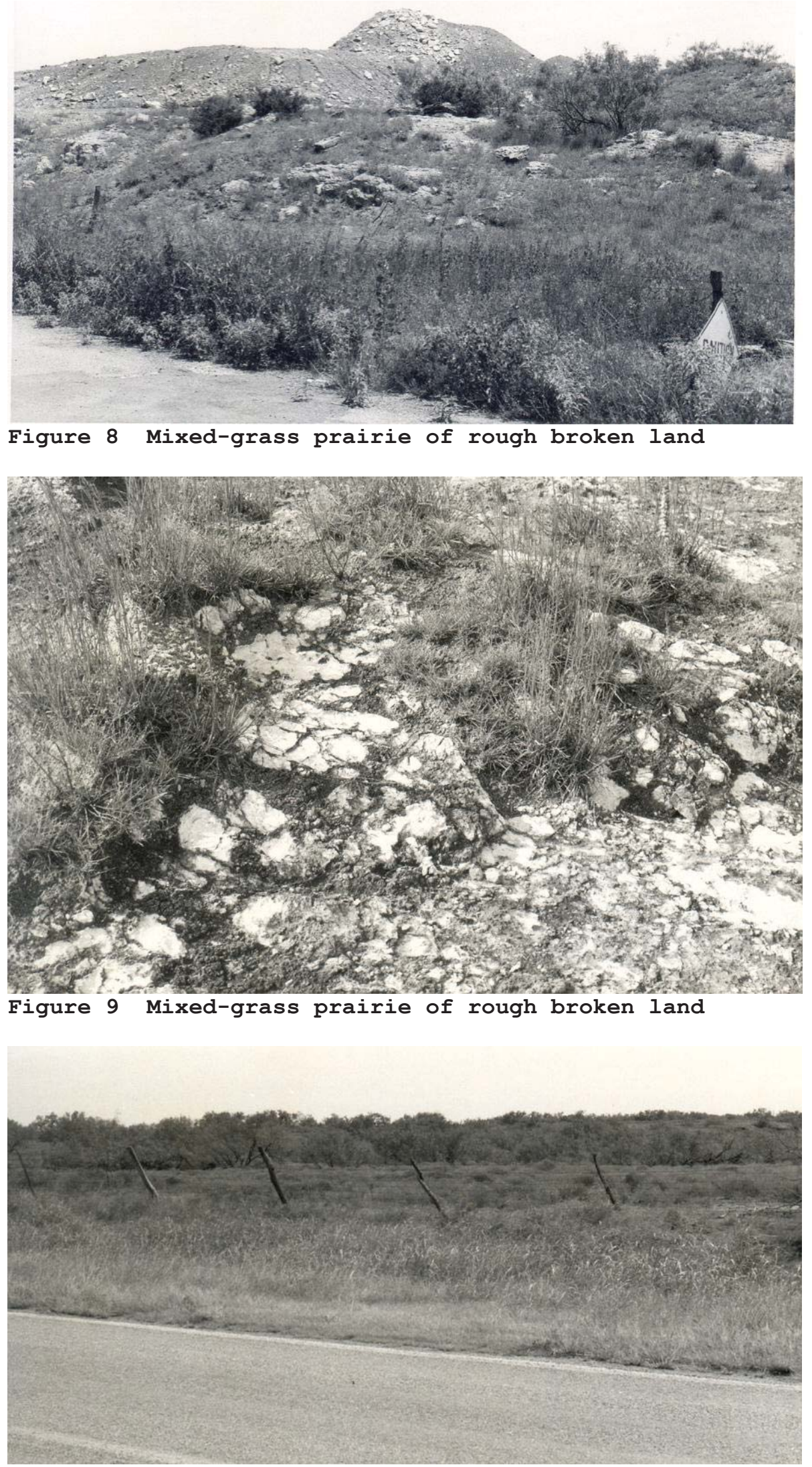

Figure 10 Mixed-grass and mesquite grassland of Tillman-Hollister

Barber, S.C. 


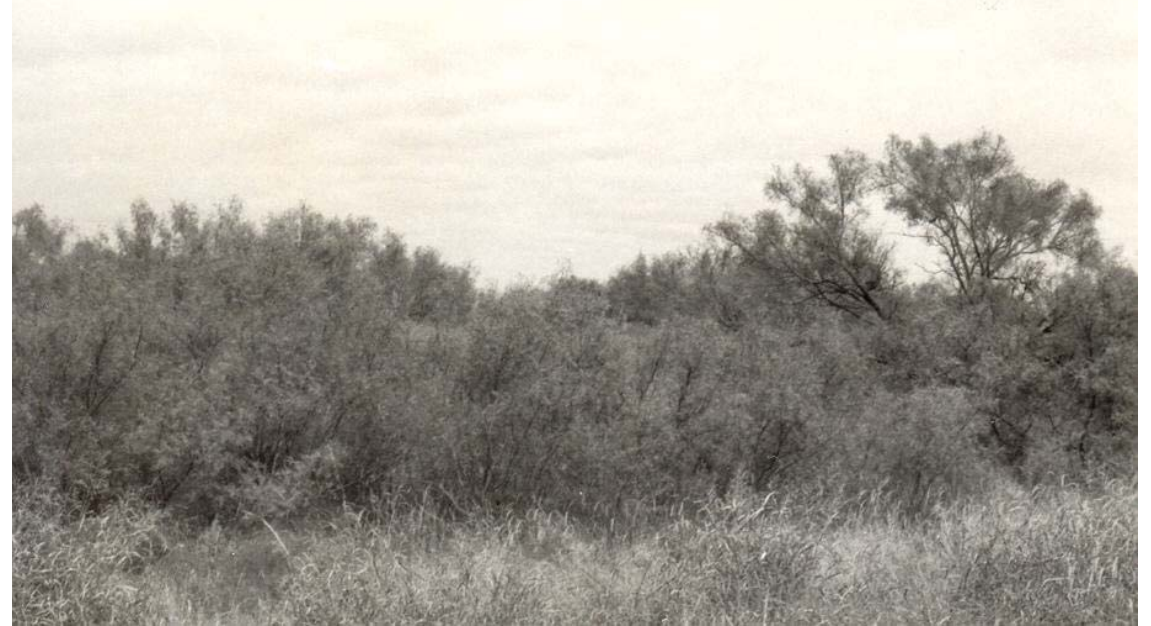

Figure 11 Mixed-grass and mesquite grassland of Tillman-Hollister

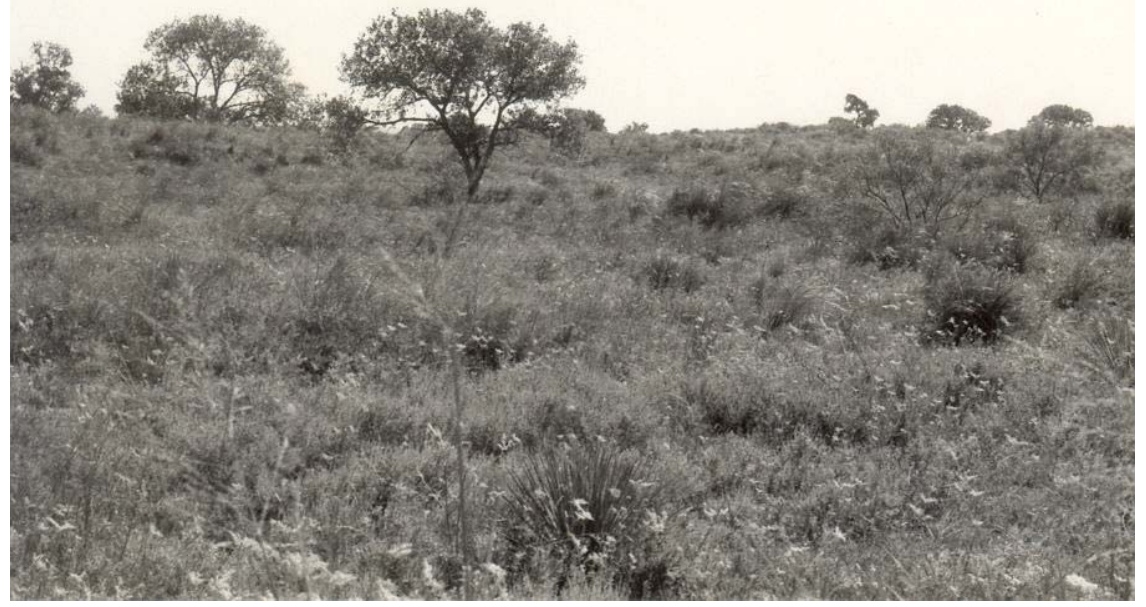

Figure 12 Sandsage grassland association

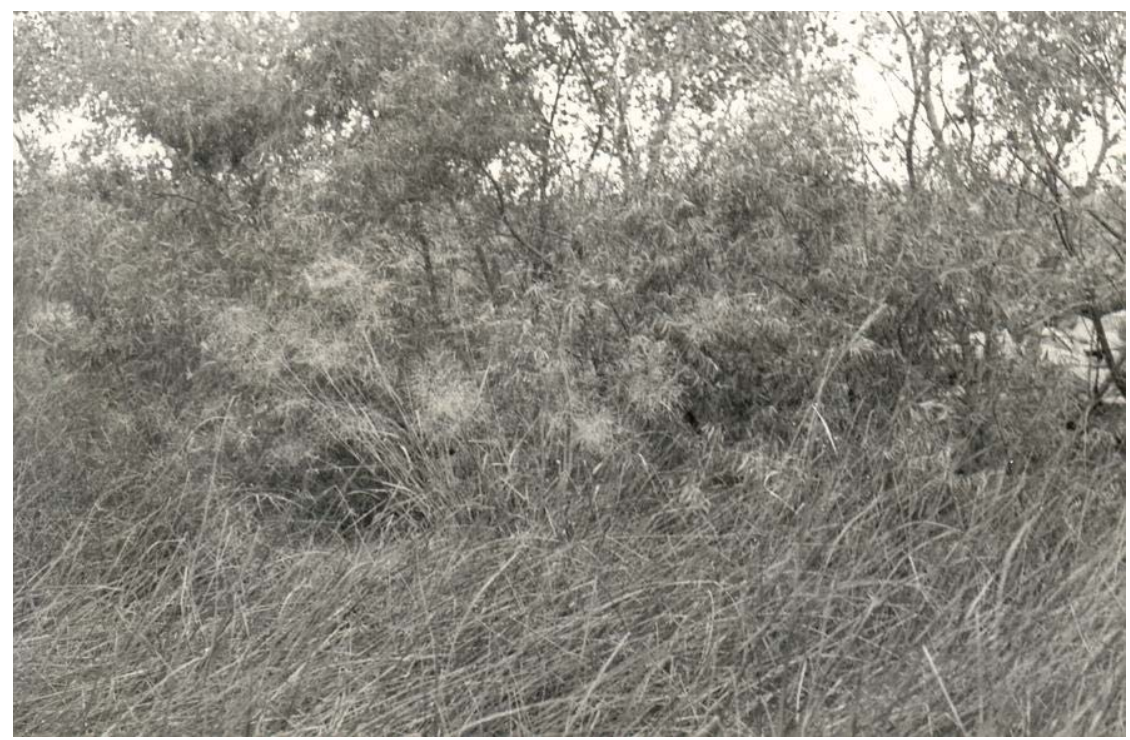

Figure 13 Woodland and Scirpus marsh area of river flood plain

Barber, S.C. 


\section{A COMPARISON OF THE GYPSUM AND REDBED TAXA}

An important aspect of the study was the comparison of the gypsum and redbed floras. One hundred eighty-seven species were found to occur on the redbed plains soils, excluding the sand areas; whereas 108 species were found on gypsum. Although gypsum soils are very fertile, they are often shallow and very dry, conditions that are not conducive to plant growth. Application of gypsum to soils causes an increase in exchangeable calcium and a decrease in exchangeable sodium, thus improving physical conditions for soil and plant growth.

Magnesium, potassium, and nitrogen levels all increase within a plant in the presence of gypsum (Poonia and Bhumbla, 1973). However, soils of 100\% gypsum exhibited a marked decrease of the same nutrients.

The aspects of the two areas are certainly distinct as can be seen from the previous discussion of the two grassland communities which coincide quite well with the gypsum and redbed soil types.

A comparison of the floras is given below where $\mathrm{G}=$ Gypsum and $\mathrm{R}$ $=$ Redbeds. The list excludes sand species.

\begin{tabular}{|c|c|}
\hline Taxa & Soils \\
\hline \multicolumn{2}{|l|}{ MARSILEACEAE } \\
\hline Marsilea vestita & $\mathrm{R}$ \\
\hline \multicolumn{2}{|l|}{ POLYPODIACEAE } \\
\hline Pellaea atropurpurea & G \\
\hline \multicolumn{2}{|l|}{ CURPRESSACEAE } \\
\hline Juniperus pinchotii & G \\
\hline J. virginiana & $\mathrm{R}$ \\
\hline \multicolumn{2}{|l|}{ GNETACEAE } \\
\hline Ephedra antisyphilitica & G \\
\hline \multicolumn{2}{|l|}{ GRAMINEAE } \\
\hline Agropyron gerardii & $\mathrm{R}$ \\
\hline Aristida fenderliana & $\mathrm{R}$ \\
\hline
\end{tabular}

A. longiseta G

A. oligantha R

A. purpurea R

A. wrightii R

Arundo donax R

Avena sativa R

Bothriochloa ischaemum R

$B$. saccharoides R

Bouteloua dactyloides $\quad G \& R$

B. curtipendula G\&R

B. gracilis $\mathrm{G} \& \mathrm{R}$

B. hirsuta $G \& R$

Elymus canadensis $\quad G \& R$

E. virginicus R

Erioneuron pilosum G\&R

Pascopyrum smithii R

Phalaris caroliniana R

Pleuraphis mutica G

Poa arachnifera R

Polypogon monseliensis $\quad R$

Schedonnardus paniculatus G

Schizachyrium scoparium G\&R

Sorghastrum nutans R

Sporobolus airoides G

S. asper G\&R

S. cryptandrus G

Tridens albescens G\&R

T. flavus G

T. muticus var. elongatus G COMMELINACEAE

Tradescantia ohiensis R

LILIACEAE

Yucca glauca G\&R

IRIDACEAE

Sisyrinchium angustifolium R POLYGONACEAE

Eriogonum annum R R

E. longifolium R R

CHENOPODIACEAE

Atriplex canescens G

AMARANTHACEAE

Kallstroemia parviflora R

NYCTAGINACEAE

Mirabilis linearis $\quad G \& R$

ILLECEBRACEAE

Paronychia jamesii G\&R

RANUNCULACEAE

Anemone caroliniana R

Delphinium carolinianum ssp. virescens R $R$

Myosurus minimus R

CRUCIFERAE

Erysimum repandum R

Lepidium austrinum R

L. virginicum R

Lesquerella gordonii G\&R

Barber, S.C. 


\section{LEGUMINOSAE}

Acacia angustissima

var. hirta

Astragalus lindheimeri

$G \& R$

A. lotiflorus

A. missouriensis

A. mollissimus

A. nuttallianus

A. plattensis

A. racemosus

Chamaecrista fasciculate

Dalea aurea

D. candida

D. enneandra

Hoffmanseggia glauca

Mimosa borealis

M. microphylla

Pediomelum cuspidatum

Prosopis glandulosa

Psoralidium tenuiflora

LINACEAE

Linum pratense
L. rigidum
oxALIDACEAE
Oxalis corniculata

o. dillenii

GERANIACEAE

Erodium texanum

Geranium carolinianum

POLYGALACEAE

Polygala alba

RHAMNACEAE

Ziziphus obtusifolia

MALVACEAE

Sphaeralcea coccinea G\&R

LOASACEAE

Mentzelia decapetala G\&R

M. nuda

M. oligosperma G

M. stricta G\&R

CACTACEAE

Cylindropuntia davisii

C. leptocaulis

Echinocactus texsensis

Echinocerreus reichenbachii

Opuntia humifusa

ONAGRACEAE

Calylophus hartwegii

$$
\text { ssp. fendleri }
$$

C. hartwegii

$$
\text { ssp. pubescens }
$$

Gaura longiflora

G. parviflora

G. sinuata

G. suffulta

Oenothera triloba

stenosiphon linifolius
G $\& R$

G

$R$

G

G

$\mathrm{R}$

$R$

$\mathrm{G} \& \mathrm{R}$

$R$

$G \& R$

$G \& R$

$G \& R$

$G \& R$

$G \& R$

$G \& R$

$G \& R$

$\mathrm{G} \& \mathrm{R}$

$\mathrm{R}$

$\mathrm{R}$

$G \& R$

$\mathrm{R}$

G

G

$R$

G

$R$

$G \& R$

$G \& R$

R

$G \& R$

G

$R$

$\mathrm{R}$

$R$

$R$

$\mathrm{G} \& \mathrm{R}$

\section{UMBELLIFERAE}

Ammoselinum popei $\quad G \& R$

Cymopterus macrorhizus G\&R

Lomatium foeniculaceum

ssp. daucifolium R

PRIMULACEAE

Androscace occidentalis R

Samolus ebracteatus R

ASCLEPIADACEAE

Asclepias engelmanniana G

Matelea biflora G\&R

CONVOLVULACEAE

Evolvulus nuttalianus $\quad$ R

HYDROPHYLLACEAE

Nama hispidum

N. stevensii

Phacelia integrifolia

BORAGINACEAE

Lappula occidentalis

var. occidentalis

L. occidentalis

var. copulata

VERBENACEAE

Glandularia canadensis G\&R

Verbena halei

LABIATAE

Hedeoma drummondii G\&R

Monarda citriodora G\&R

Salvia azurea R

Scutellaria drummondii G

S. wrightii

Teucrium laciniatum

SOLANACEAE

Chamaesaracha coniodes G\&R

Physalis lobata R

P. viscosa

SCROPHULARIACEAE

Castilleja purpurea

var. citrina

Penstemon albidus

P. fenderli

PLANTAGINACEAE

Plantago purshii G\&R

RUBIACEAE

Hustonia humifusa R

CAMPANULACEAE

Triodanis holzingeri

COMPOSITAE

Aphanostephus ramosissimus

Berlandiera lyrata

Centauries americana

Chaetopappa ericoides

Evax verna

Gaillardia pinnatifida

G. pulchella

G. suavis

Grindelia nuda

$\mathrm{G} \& \mathrm{R}$

G

R

$\mathrm{R}$

$\mathrm{G} \& \mathrm{R}$

$R$

$G \& R$

$G \& R$

$G \& R$

$G \& R$

$G \& R$

$R$

G

Barber, S.C. 
Oklahoma Native Plant Record

Volume 8, Number 1, December 2008

$\begin{array}{lr}\text { Haploesthes greggii } & \text { G } \\ \text { Heterotheca canescens } & \text { R } \\ \text { H. stenophyla } & \text { G } \\ \text { Hymenoxys odorata } & \text { G\&R } \\ \text { Liatris punctata } & \text { G\&R } \\ \text { Lindheimera texana } & \text { G\&R } \\ \text { Machaeranthera } & \\ \quad \text { Pennatifida } & \text { G\&R } \\ \text { Psilostrophe tagetina } & \\ \quad \text { var. cerifera } & \text { G } \\ \text { Pyrrhopapus multicaulis } & \mathrm{R} \\ \text { Symphyotrichum ericoides } & \mathrm{G} \& \mathrm{R} \\ \text { S. oblongifolium } & \mathrm{R} \\ \text { S. subulatum } & \mathrm{R} \\ \text { Tetraneuris scaposa } & \mathrm{R} \\ \text { Thelesperma megapotamicum } & \mathrm{R} \\ \text { Zinnia grandiflora } & \mathrm{G} \& \mathrm{R}\end{array}$

Of the 108 species occurring on the gypsum, the author discovered that only 30 were found exclusively on the gypsum. Seven of the 30 have herbarium records indicating occurrence only on gypsum. They include:

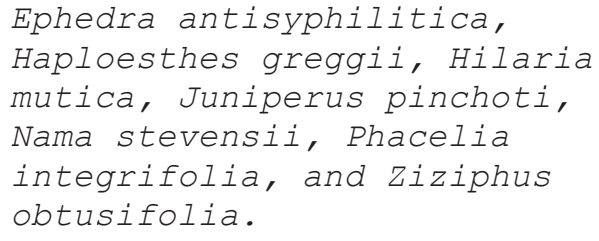

Six other species which the author collected and observed only on gypsum appear to be good gyp indicators. These and the previous seven are considered Gypsophiles and indicators of gypsum soils. They are:

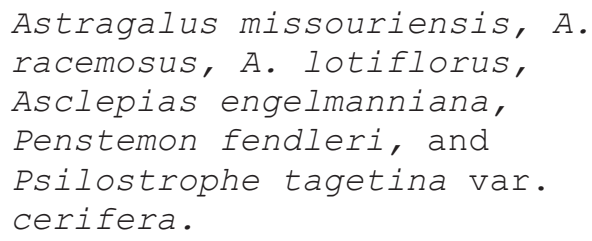

The herbarium records of the above show one or two sheets which were not collected on gypsum. Nine taxa found here only on the gypsum are reported also from limestone soils, especially the Arbuckle Mountains and parts of Cimarron County. Russell (1969) states that calcareous soils free from sodium salts cannot have a $\mathrm{pH}$ exceeding
8.4, but the plants do not often do well in the soils because iron, manganese, boron, and perhaps other trace elements are so insoluble in these soils. He also points out that potassium deficiency sometimes induces iron deficiency or chlorosis and that this is a characteristic trouble of calcareous soils. Calcareous soils in excess can be harmful. It seems then that plants common to the limestone and gypsum have adapted to the situation.

The list of plants occurring almost exclusively on the gypsum and limestone are the following:

Aristida longiseta, Astragalus mollissimus, A. plattensis, Cylindropuntia leptocaulis (1 sheet from limestone area), Mentezelia nuda, $M$. oligosperma, Polygala alba (also from prairie sites of deep soils), Scutellaria drummondii, and Tridens muticus var. elongatus (also Wichita Mountains).

The other eight species of the thirty species were collected by the author only on gypsum, but do occur elsewhere. These are the following:

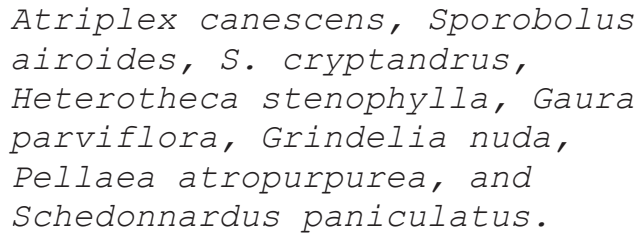

It should be noted that sporobolus cryptandrus was most often observed on sand in the area, but was collected and observed on the gypsum several times. Schedonnardus paniculatus occurs in mostly sandy disturbed areas in the rest of the state. This grass was found in an area disturbed by gypsum mining. Atriplex canescens and sporobolus airides occur only in saline sites in other parts of the state. 


\section{ADDITIONS TO THE FLORA OF OKLAHOMA AND TAXA OF SPECIAL SIGNIFICANCE}

Two introduced species Bromus willdenowii and Caesalpinia gilliesii are believed to be new additions to the state flora. No specimens are deposited in the two large herbaria of the state, the Bebb Herbarium at the University of Oklahoma and the Oklahoma state Herbarium. Caesalpinia gilliesii (AcC. No. 908) is a native of South America and is often found as an escape in central and West Texas. The species was found growing on the floodplain of the Red River, R20W, T2S, Sec. 11, and several individual shrubs were growing in the area. The plant was most likely cultivated for its showy flowers at the old homestead and escaped to the floodplain.

The distinctions between Bromus willdenowiii and Bromus unioloides have been previously discussed by Raven (1960) and Beetle (1972). The species are very closely related, but the author believes AcC. No. 668 to be B. willdenowii. The species is a native of South America and according to Gould (1965) is quite common on the coast of Texas. The species was introduced into the United States as a forage grass and apparently has escaped in many areas. It is distinguished from $B$. unioloides on the basis of spikelet color, lemma length, and arrangement of spikelets.

In addition to the additions to the state flora, 18 other taxa are considered somewhat significant. These specimens are represented by six or less sheets in the Oklahoma State Herbarium.

Asclepias arenaria Torr. (AcC. No. 953). This species is represented by three sheets but is a widespread species in the Plains Country of Texas. The plants seem to occur sporadically, therefore they could have been easily missed by collectors making one trip into the area.
Asclepias engelmanniana Woods. (Acc. No 986). This taxon is represented by five sheets and is very closely related to $A$. stenophylla. The two are quite difficult to delimit, therefore some of the herbarium material may be misidentified. This taxon is interesting in that it was only found on the gypsum soils in the study area.

\section{Aphanostephus ramosissimus Buckl.} (Acc. No. 670). This taxon is very similar in aspect to $A$. skirrhobasis and A. pilosus. It actually seems quite abundant in the area and has probably been overlooked by collectors due to the similar appearance of its relatives.

\section{Atriplex canescens (Pursh) Nutt.} (AcC. No. 841). Although only four sheets are in the herbarium, this species is widespread on alkaline soils in Texas. It was only found on gypsum soils in the study area.

Berlandiera lyrata Benth. var. lyrata (ACC. No. 711). Although this species is represented by only six sheets in the OSU herbarium, it is well represented in the Bebb Herbarium. However, this taxon has been previously collected in Cimarron county in oklahoma. This is quite a range extension for the state, but is not too unlikely in that the species occurs in the Texas Panhandle.

Chilopsis linearis (Cav.) Sweet. (AcC. No. 955). This taxon is represented by one sheet and was collected as a member of a shelter belt in Caddo County. This collection was also made in a shelter belt. The plant is native in the Trans-Pecos of Texas.

\section{Echinocactus texensis Hopffer.}

(Acc. No. 725). There are no sheets of this species from Oklahoma in the OSU herbarium. Waterfall (1969) lists the species as occurring in the state. Correll and Johnston (1970) give a very

Barber, S.C. 
Oklahoma Native Plant Record

Volume 8, Number 1, December 2008

limited distribution for the species in Texas and Mexico. The species was observed only one time in the study area in a mesquite grassland area near Eldorado. It seems to be a relatively rare species.

\section{Echinocereus reichenbachii} (Terscheck) Haage (ACC. No. 1109). This species is represented by three sheets, but is actually quite common in the study area. It probably has not been collected more often due to the difficulty in pressing and preserving cacti.

Haploethes graggii Gray (AcC. No. 984). This taxon is represented by five sheets. It is an apparent gypsum endemic and has probably not been collected more often in the state because the gypsum areas have not been well collected.

Houstonia humifusa (A. Gray) A. Gray (Acc. No. 664). Although there are only two sheets represented of this species, it is quite common in the Plains country of Texas. Most likely it has been overlooked by plant collectors because it is very inconspicuous.

Helenium microcephalum DC. (ACC. No. 932). Four sheets of this species are represented and are all from the southwestern part of the state. The plant also occurs in seasonally moist areas. Combining these two factors, the species has most likely just been overlooked.

Pleuraphis mutica Buckley (AcC. No. 927). This species was only found on the gypsum soils in the study area and only occurred on two of the collection sites. However, it is locally quite abundant.

Matelea biflora (Raf.) Woods.

(Acc. No. 853). There is only one sheet represented in the herbarium. This plant was only observed in two localities and was not abundant either place. It could quite easily be overlooked by a plant collector also because it blends in with the vegetation surrounding it.

Cylindropuntia davisii (Engelm. \& Bigelow) F.M. Knuth (ACC. No. 996). There is one collection of this species represented in the herbarium. It was seen only at one location by the author. Also, the spines are approximately four centimeters long and are very painful and make the specimen difficult to press so it has probably been passed by, by many collectors.

Cylindropuntia leptocaulis (DC.) F.M. Knuth (ACC. No. 935). This species is quite often seen in the study area and has probably not been collected more often due to the difficulty in pressing.

Setaria leucophilia (Scribn. \& Merr.) K. Schum. (Acc. no. 1022). There is one representative of this species and is reported by Correll and Johnston (1970) to occur on the Rio Grande Plains, Trans-Pecos, and Plains Country of Texas. Most likely the taxon has just extended its range into southwestern Oklahoma.

Triodanis holzingeri McVaugh. (Acc. no. 767). There are no sheets of this species in the herbarium, but it is reported by Waterfall (1969) to occur in the state. Correll and Johnston (1970) report that it occurs in open plains, therefore it is probably not rare, just overlooked by collectors.

Triodanis perfoliata (L.) Nieuw. (Acc. no. 877). There are only three collections of this taxon, but the plant seems quite weedy, therefore it has probably been overlooked as unimportant to collect. 


\section{SUMMARY}

During the collecting season of 1975, 542 accessions were made by the author and the identified specimens deposited in the Oklahoma state and the Bebb herbaria. From these specimens and 26 others collected by U.T. Waterfall and G.W. Stevens, a list of the vascular plants of the redbed plains and gypsum hills regions of southwestern Oklahoma was compiled. The list contains 63 families, 230 genera, 354 species, and 359 different taxa. Thirty species were found to grow only on gypsum soils. Approximately 60\% of the taxa are from seven families: Compositae, 69; Graminae, 65; Leguminosae, 29; Onagraceae, 13; Euphorbiaceae, 12; Cruciferae, 11; and Solanaceae, 10. Two introduced species Bromus catharticus Vahl (syn. = Bromus willdenowii) and Caesalpinia gilliesii are listed as additions to the state flora and eighteen taxa are discussed as being infrequently collected and especially significant.

\section{SELECTED REFERENCES}

Abert, J.W. 1846. Journal of Lieutenant J.W. Abert from Bent's Fort to st. Louis in 1845. U.S. 29th Cong. 1st Sess., Sen. Doc. No. 8: No. $438,1-75$.

Bailey, D.F. and R.D. Graft. 1961. Soil survey of Jackson $67 \mathrm{p}$. with maps.

Beetle, A.A. 1972. Ceratochloa of Bromus H.B.K. in Mexico. Contribuciones al Estudio de las Gramineas de Mexico.

Bigelow, J.M. 1855. General description of the botanical character of the country. In: Report on the exploration and survey, Mississippi River to the Pacific Ocean. U.S. $33^{\text {rd }}$ Cong., $2^{\text {nd }}$ Sess., Sen. Exec. Doc. No. 78. 4: 1-4.

Blair, W.F. and T.H. Hubbell. 1938. The biotic districts of Oklahoma. Amer. Midland Nat. $20: 425-455$.
Bowden, W.M. 1959. The taxonomy and nomenclature of the wheats, barleys, ryes, and their wild relatives. Canad. Journ. Bot. $37: 657-684$.

Bruner, W.E. 1931. The vegetation of Oklahoma. Ecol. Monogr. 1: 99-188.

Bull, R.Z. 1932. Vascular Plants of Greer County. M.S. Thesis. University of Oklahoma

Clifton, R.L. 1928. Oil and gas in oklahoma, geology of Harmon, Greer, Jackson, and Tillman counties. Okla. Geol. Surv. Bull. 40: 191-210.

Correll, D.S. and M.C. Johnston. 1970. Manual of the vascular plants of Texas. Texas Research Foundation, Renner, TX. 1879 p.

Curtis, N.M., W.E. Ham, K.S. Johnson, C.C. Branson, S.E. Marcher, and J.F. Roberts. 1972. Geology and earth resources of Oklahoma. Okla. Geol. Surv. Educ. Publ. No. 1. $8 \mathrm{p}$.

Duck, L.G. and J.B. Fletcher. 1943. A game type map of Oklahoma. Div. of Wildlife Restoration, Okla. Game and Fish Dept., Oklahoma City, Oklahoma.

Featherly, H.I. 1943. The cavalcade of botanists in Oklahoma. Proc. Okla. Acad. Sci. 23: 10-14.

Fenneman, N.M. 1922. Physiographic provinces and sections in western oklahoma and adjacent parts of Texas. U.S. Geol. Surv. Bull. 730: 115-134.

Frie, J.W., R.C. Brinlee, and R.D. Graft. 1967. Soil Survey of Greer county. 72 p. with maps.

Gould, C.N. 1904. Gypsum deposits in Oklahoma. US. Geol. Surv. Bull. 223: 60-67. - 1910. Brief chapters on Oklahoma's minerals. Okla. Geol. Surv. Bull. 6: 33-95. - 1911. Preliminary report on structural materials of Oklahoma. Okla. Geol. Surv. Bull 5: $182 \mathrm{p}$. - 1913. Petroleum in the red beds of Oklahoma. Economic 
Oklahoma Native Plant Record

Volume 8, Number 1, December 2008

Geol. 8: 768-780.

Gould, F.W. 1956. Chromosome counts and cytotaxonomic notes on some grasses of the tribe Andropogoneae. Amer. Jour. Bot. 43: 395-404.

- 1967. The grass genus

Andropogon in the United

States. Britt. 19: 70-76. and T.W. Box. 1965. Grasses

of the Texas Coastal Bend.

Texas A \& M University Press. $186 \mathrm{p}$.

Grant, Verne. 1956. A synopsis of Ipomopsis. El Aliso 3: 351-362.

Ham, W.E. 1964. Basement rocks and structural evolution of southern Oklahoma. Okla. Geol. Surv. Bull. 95: 302 p.

Hanson, W.E. 1941. Early botanists of Oklahoma. M.S. Thesis Oklahoma state University, Stillwater Oklahoma.

Hitchcock, A.S. and Agnes Chase. 1951. Manual of the grasses of the United States. 2nd ed. U.S.D.A. Misc. Publ. No. 200. $1051 \mathrm{p}$.

Johnson, K.S. 1964. New gypsum plant to open at Duke, Jackson County, Oklahoma. Okla. Geol. Notes, $24(1) ; 3-8$. and W.E. Ham. 1964. Copper in flowerpot Shale (Permian) of the Creta area, Jackson County, oklahoma. Okla. Geol. Surv. Circ. 64: $32 \mathrm{p}$.

Kelting, R.W. and Wm. T. Penfound. 1953. Literature on the vegetation of Oklahoma. Proc. Okla. Acad. Sci. 34: 125-135.

Kruckeberg. 1951. Intraspecific variability in the response of certain native plant species to serpentine soil. Amer. Jour. Bot. 38: 408-419.

Marcy, R.B. 1854. Explorations of the Red River of Louisiana in the year 1852. U.S. 33 $3^{\text {rd }}$ Con., 1st Sess. Ho. of Reps. Doc. 54.

McKelvey, S.D. 1955. Botanical exploration of the TransMississippi west. Arnold Arboretum, Jamaica Plain, Mass. $1144 \mathrm{p}$.

Pohl. R.W. 1968. How to know the grasses. Wm.C. Brown Co.,
Dubuque, Iowa. $244 \mathrm{p}$.

Poonia S.R. and D.R. Bhumbla. 1972. Effect of gypsum and calcium carbonate on plant yield and chemical composition and calcium availability in a non-saline sodic soil. Plant and Soil 38: 71-80.

Raven, P.H. 1960. The correct name for rescue grass. Britt. 12: 219-221.

- 1964. The generic

subdivisions of Onagraceae, tribe Onagraceae. Britt. 16: 276-288.

Russell, E.J. 1961. Soil Conditions and Plant Growth. Jarrold and Sons, Ltd.

Rowell, C.M., Jr. 1967. Vascular plants of the Texas Panhandle and South Plains. PhD. Thesis. oklahoma state University.

Snider, L.C. 1913. The gypsum and salt of Oklahoma. Okla. Geol. Surv. Bull. 11: 206 p.

Stevens, G.W. and C.W. Shannon. 1917. Plant life in Oklahoma. Okla. Geol. Surv. Bull 27: 215246.

Tateoka, Tugo. 1961. A biosystematic study of Tridens. Amer. Jour. Bot. 48: 565-573.

Turner, B.L. 1973. Two new gypsophilous species of Marchaeranthera from Northcentral Mexico. Phytologia $26(2)$ : 116-120.

U.S.D.A. Soil Conservation Service. 1973. Harmon County Conservation District Report.

U.S. Department of Commerce. 1967. Census of Mineral Industries. Dept of Commerce Publ. MIC 67: 2-35.

U.S. Department of commerce. 1970 . Census of Populations. Dept. of "Commerce Publ. PC(VI) - 38 .

U.S. Department of Commerce. 1969. Census of Agriculture. Dept. of Commerce Publ. AC 69 (1) -361.

Waterfall, U.T. 1950. Some additions to the Oklahoma flora. Rhodora 52: 19-23. - 1969. Keys to Flora of Oklahoma. 4th ed. Privately published, Stillwater, Oklahoma. $246 \mathrm{p}$. 
TABULAR VIEW OF FAMILIES: GENERA (G) SPECIES (S); SPECIES AND SUBORDINATE TAXA (SS)

\begin{tabular}{|c|c|c|c|}
\hline & G & S & SS \\
\hline AMARANTHACEAE & 2 & 2 & 2 \\
\hline ANACARDIACEAE & 1 & 3 & 3 \\
\hline ASCLEPIADACEAE & 3 & 5 & 5 \\
\hline BIGNONIACEAE & 3 & 3 & 3 \\
\hline BORAGINACEAE & 3 & 4 & 4 \\
\hline CACTACEAE & 3 & 5 & 5 \\
\hline CAMPANULACEAE & 1 & 2 & 2 \\
\hline CARYOPHYLLACEAE & 3 & 3 & 3 \\
\hline CHENOPODIACEAE & 5 & 7 & 7 \\
\hline COMMELINACEAE & 2 & 3 & 3 \\
\hline COMPOSITAE & 45 & 66 & 69 \\
\hline CONVOLVULACEAE & 4 & 4 & 4 \\
\hline CRUCIFERAE & 9 & 11 & 11 \\
\hline CUCURBITACEAE & 2 & 2 & 2 \\
\hline CUPRESSACEAE & 3 & 4 & 4 \\
\hline CYPERACEAE & 5 & 12 & 12 \\
\hline EUPHORBIACEAE & 5 & 12 & 12 \\
\hline FAGACEAE & 1 & 1 & 1 \\
\hline GERANIACEAE & 2 & 3 & 3 \\
\hline GNETACEAE & 1 & 1 & 1 \\
\hline GRAMINEAE & 35 & 65 & 65 \\
\hline HYDROPHYLLACEAE & 2 & 3 & 3 \\
\hline ILLECEBRACEAE & 1 & 1 & 1 \\
\hline IRIDACEAE & 1 & 1 & 1 \\
\hline KRAMERIACEAE & 1 & 1 & 1 \\
\hline LABIATAE & 6 & 9 & 9 \\
\hline LEGUMINOSAE & 18 & 29 & 29 \\
\hline LILIACEAE & 4 & 4 & 4 \\
\hline LINACEAE & 1 & 2 & 2 \\
\hline LOASACEAE & 1 & 2 & 2 \\
\hline LYTHRACEAE & 1 & 1 & 1 \\
\hline MALVACEAE & 3 & 5 & 6 \\
\hline
\end{tabular}

\begin{tabular}{|c|c|c|c|}
\hline & G & S & SS \\
\hline MARS I LEACEAE & 1 & 1 & 1 \\
\hline MARTYNIACEAE & 1 & 1 & 1 \\
\hline MORACEAE & 2 & 2 & 2 \\
\hline NYCTAGINACEAE & 3 & 3 & 3 \\
\hline OLEACEAE & 1 & 1 & 1 \\
\hline ONAGRACEAE & 4 & 12 & 13 \\
\hline OXALIDACEAE & 1 & 2 & 2 \\
\hline PAPAVERACEAE & 1 & 1 & 1 \\
\hline PLANTAGINACEAE & 1 & 4 & 4 \\
\hline PLUMBAG INACEAE & 1 & 1 & 1 \\
\hline POLEMONIACEAE & 1 & 1 & 1 \\
\hline POLYGALACEAE & 1 & 1 & 1 \\
\hline POLYGONACEAE & 3 & 7 & 7 \\
\hline POLYPODIACEAE & 1 & 1 & 1 \\
\hline PORTULACACEAE & 1 & 1 & 1 \\
\hline PRIMULACEAE & 2 & 2 & 2 \\
\hline RANUNCULACEAE & 3 & 3 & 3 \\
\hline RHAMNACEAE & 1 & 1 & 1 \\
\hline ROSACEAE & 1 & 1 & 1 \\
\hline RUBIACEAE & 1 & 2 & 2 \\
\hline SALICACEAE & 2 & 2 & 2 \\
\hline SAP INDACEAE & 1 & 1 & 1 \\
\hline SCROPHULARIACEAE & 3 & 6 & 6 \\
\hline SOLANACEAE & 6 & 10 & 10 \\
\hline TAMARICACEAE & 1 & 1 & 1 \\
\hline TYPHACEAE & 1 & 1 & 1 \\
\hline ULMACEAE & 2 & 4 & 4 \\
\hline UMBELLIFERAE & 6 & 6 & 6 \\
\hline VERBENACEAE & 1 & 5 & 5 \\
\hline VITACEAE & 1 & 1 & 1 \\
\hline ZYGOPHYLLACEAE & 2 & 2 & 2 \\
\hline Families & G & S & SS \\
\hline TOTALS 230 & 54 & 359 & 359 \\
\hline
\end{tabular}

Barber, S.C. 